\title{
Transport of aerosols over the French Riviera - link between ground-based lidar and spaceborne observations
}

\author{
Patrick Chazette $^{1}$, Julien Totems ${ }^{1}$, and Xiaoxia Shang ${ }^{1, a}$ \\ ${ }^{1}$ Laboratoire des Sciences du Climat et de l'Environnement (LSCE), CEA-CNRS-UVSQ, UMR 8212, Gif-sur-Yvette, France \\ a now at: Finnish Meteorological Institute, P.O. Box 1627, 70211, Kuopio, Finland
}

Correspondence: Patrick Chazette (patrick.chazette@1sce.ipsl.fr)

Received: 12 September 2018 - Discussion started: 3 December 2018

Revised: 14 February 2019 - Accepted: 3 March 2019 - Published: 26 March 2019

\begin{abstract}
For the first time, a $355 \mathrm{~nm}$ backscatter $\mathrm{N}_{2}$-Raman lidar has been deployed on the western part of the French Riviera to investigate the vertical aerosol structure in the troposphere. This lidar system, based at the AERONET site of Toulon-La Garde, performed continuous measurements from 24 June to 17 July 2014, within the framework of the multidisciplinary program Mediterranean Integrated Studies at the Regional and Local Scales (MISTRALS). By coupling these observations with those of the spaceborne instruments Cloud-Aerosol LIdar with Orthogonal Polarization (CALIOP), Spinning Enhanced Visible and InfraRed Imager (SEVIRI), and Moderate Resolution Imaging Spectroradiometers (MODIS), the spatial extents of the aerosol structures are investigated. The origins of the aerosol plumes are determined using back trajectories computed by the Hybrid Single Particle Lagrangian Integrated Trajectory (HYSPLIT). This synergy allowed us to highlight plumes of particulate pollutants moving in the low and medium free troposphere (up to $\sim 5 \mathrm{~km}$ above the mean sea level) towards the French Riviera. This pollution originates from the Spanish coast, more particularly from Costa Blanca (including Murcia) and Costa Brava-Costa Daurada (including Barcelona). It is mainly due to traffic, but also to petrochemical activities in these two regions. Desert aerosol plumes were also sampled by the lidar. The sources of desert aerosols have been identified as the Grand Erg Occidental and Grand Erg Oriental. During desert dust events, we highlight significant differences in the optical characteristics in terms of the backscatter-to-extinction ratio (BER, inverse of the lidar ratio) between the planetary boundary layer, with $0.024 \mathrm{sr}^{-1}$ $(\sim 42 \mathrm{sr})$, and the free troposphere, with $0.031 \mathrm{sr}^{-1}(\sim 32 \mathrm{sr})$. These differences are greatly reduced in the case of pol-
\end{abstract}

lution aerosol plume transport in the free troposphere (i.e., 0.021 and $0.025 \mathrm{sr}^{-1}$ ). Transported pollution aerosols appear to have similar BER to what is emitted locally. Moreover, using the correlation matrix between lidar aerosol extinction profiles as a function of altitude, we find that during transport events in the low free troposphere, aerosols may be transferred into the planetary boundary layer. We also note that the relative humidity, which is generally higher in the planetary boundary layer ( $>80 \%$ ), is found to have no significant effect on the BER.

\section{Introduction}

The French Riviera region is the most densely populated area of southern France with, as of 2018, about 4.2 million inhabitants in the Provence-Alpes -Côte d'Azur counties bordering the Mediterranean Sea and the Principality of Monaco. The greater Côte d'Azur region is also the first tourist destination in France after Paris, with 20 million tourists generating over 130 million overnight stays every year, as well as 1.2 million cruise passengers, increasing traffic pollutants, especially in summer. Between 1990 and 2005, a marked increasing trend for $\mathrm{PM}_{10}$ ambient concentrations was observed in this area, correlated with an increase in airway diseases (Sicard et al., 2010). The impact of local traffic is predominant in the summer season, but the industries in the Bouche du Rhône area are also large contributors (El Haddad et al., 2013), and the impact of exogenous sources other than Saharan dust is not negligible (Dimitriou and Kassomenos, 2018). In the coastal town of Toulon, centrally located on the French Riviera, Piazzola et al. (2012) have shown during specific events that 
air masses could be impacted by pollution transported over the Mediterranean. Yet, these source apportionment studies are only based on surface chemical analyses and back trajectories, which do not take into consideration the complex meteorological environment of the coastline.

In the framework of the multidisciplinary program Mediterranean Integrated Studies at the Regional and Local Scales (MISTRALS; http://www.mistrals-home.org, last access: 15 March 2019), in particular for the ChemistryAerosol Mediterranean Experiment (ChArMEx; http:// charmex.lsce.ipsl.fr, last access: 15 March 2019) (Mallet et al., 2016), aerosols in the Mediterranean basin have been studied by several authors, either via their chemical composition (e.g., Cholakian et al., 2018), their optical properties (e.g., Chazette et al., 2016; Granados-Muñoz et al., 2016), their radiative budget (e.g., Nabat et al., 2015; Di Biagio et al., 2016; Sicard et al., 2016), or the identification of their sources (e.g., Ancellet et al., 2016; Chrit et al., 2018). Among these studies, few were conducted in the atmospheric column above the French Mediterranean coast, which may be subject to aerosol loads of very different origins and chemical compositions. These aerosols directly influence the air quality (e.g., Knipping and Dabdub, 2003), as well as the climate balance of the western Mediterranean Sea (e.g., IPCC, 2014; Nabat et al., 2015), in different ways depending on their nature and the surface albedo. For instance, during the Hydrological Cycle in the Mediterranean Experiment (HyMeX, also part of the MISTRALS program), the radiative effect of dust aerosols has been shown to have little impact on the rainfall amounts and location over the western Mediterranean basin (Flamant et al., 2015).

All of these studies were preceded by early campaigns such as that of the European project Mediterranean Dust Experiment (e.g., Hamonou et al., 1999) or even networked observations such as those of the lidar Earlinet network (e.g., Balis et al., 2000; Pappalardo et al., 2004; Papayannis et al., 2008; and more recently Granados-Muñoz et al., 2016). Coupling in situ measurements and modeling, the vertical structure of the planetary boundary layer under sea breeze conditions was also investigated during the ExperimentS to COnstrain Models of atmospheric Pollution and Transport of Emissions (ESCOMPTE; Cros et al., 2004) over the Marseille-Berre area, $\sim 40 \mathrm{~km}$ west of the French Riviera.

Little information exists describing the transboundary transport of aerosols within the free troposphere over the French Riviera. For this reason, a ground-based $\mathrm{N}_{2}$-Raman lidar was installed in this region between 24 June and 16 July 2014. The lidar has combined more than $500 \mathrm{~h}$ of continuous operation and has made it possible to carry out a significant study of aerosol types and origins in synergy with spaceborne observations and back trajectory modeling. Works performed using lidar measurements over the Balearic island of Menorca (Chazette et al., 2016) have already highlighted the long-range transport of aerosols coming from forest fires in North America (see also Ancellet et al., 2016), from deserts, and, to a lesser extent, from pollution sources located on the Costa Brava (Barcelona). During the summer period, we were not able to establish a clear link between the polluted air masses passing over Menorca and those reaching the French Riviera, suggesting another pathway and/or other aerosol sources. Moreover, previous studies carried out on the French Riviera were only based on surface observations (e.g., Piazzola et al., 2012) and have not offered the possibility of clearly identifying the origin of aerosols, which will be shown hereafter.

The experimental strategy is developed in Sect. 2, where the lidar, the signal processing, and the main uncertainty sources are presented. The temporal evolution of aerosol optical properties and the vertical atmospheric structure over the French Riviera, observed by the ground-based lidar, are discussed in Sect. 3. Section 4 is devoted to the meteorological conditions during the field campaign. The long-range transport of aerosol plumes highlighted from the lidar measurements is described in Sect. 5, using the coupling with both spaceborne measurements and back trajectory studies. Section 6 summarizes and concludes.

\section{Strategy}

The perimeter of the western Mediterranean is composed of mountains with elevations generally greater than $1000 \mathrm{~m}$ above mean sea level (a.m.s.l.). This specific morphology facilitates the recirculation of air masses, and therefore aerosols, via the sea breeze-land breeze cycle, the alternation between the katabatic and anabatic winds, and the guiding of the air mass circulation in the valleys and along the seashore. Sea breeze is an effective means of exchange between the marine or continental boundary layer and the free troposphere, especially around the Mediterranean basin (Bouchlaghem et al., 2007; Lasry et al., 2005; Levy et al., 2008; Millán et al., 1991). The aerosols trapped in the low and medium free troposphere will then be transported over long distances and may arrive over the Mediterranean coasts where they will reach the surface via free or forced convection processes generated by the mountains. This transport often happens in thin sheet-like plumes whose vertical limits are generally marked by discontinuities in the potential temperature gradient (e.g., Dalaudier et al., 1994; Chazette et al., 2001). The observation of such layers requires a profiler with a high vertical resolution and justified the deployment of an $\mathrm{N}_{2}$-Raman lidar on the French Riviera, close to the AERONET (AErosol RObotic NETwork) site of Toulon-La Garde $\left(43.13556^{\circ} \mathrm{N}\right.$, $6.00944^{\circ} \mathrm{E} ; 50 \mathrm{~m}$ elevation), which is representative of periurban conditions. The location of the site is given in Fig. 1a and $b$. The lidar performed automatic measurements from 24 June to 17 July 2014. It was remote-controlled from the Paris area. Lidar measurements are investigated together with active and passive remote sensing spaceborne observations, as well as by back trajectory studies. 

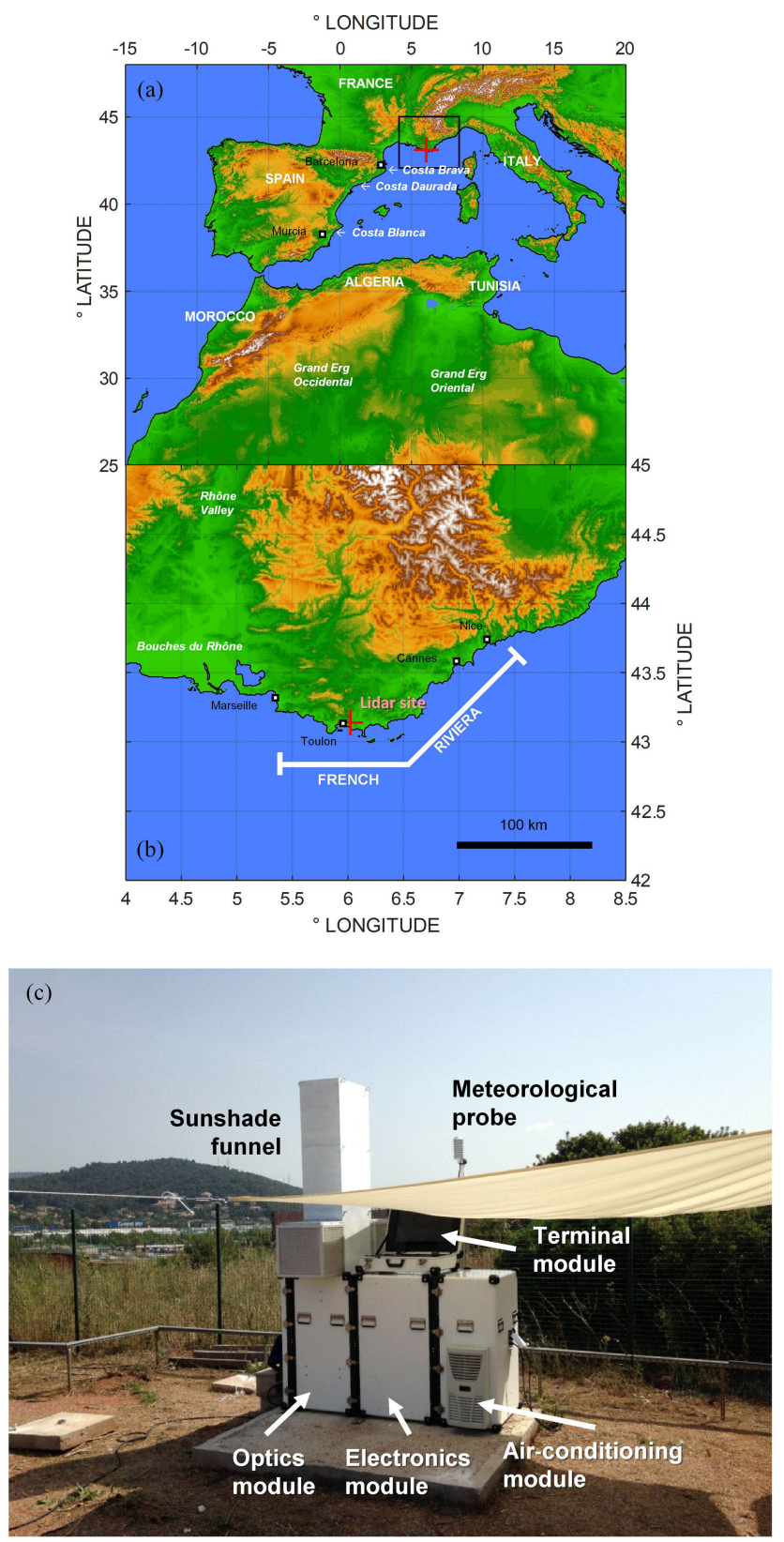

Figure 1. (a) Map of the western Mediterranean basin and (b) crop showing the location of the lidar at the Toulon-La Garde AERONET site on the French Riviera (elevation data from the GTopo30 DEM, courtesy of USGS). (c) Lidar in its confinement during the field experiment.

\subsection{The automatic $\mathrm{N}_{2}$-Raman lidar}

The $\mathrm{N}_{2}$-Raman lidar LAASURS (Lidar Automatic for Atmospheric Surveys using Raman Scattering) is a research instrument composed of three channels for parallel and perpendicular polarizations, with respect to the laser emission and the inelastic nitrogen vibrational Raman line of the laser-induced atmospheric backscattered signal (Royer et al.,
2011; Chazette et al., 2016). The lidar in its confinement is shown in Fig. 1c. The emission energy was $16 \mathrm{~mJ}$ at the wavelength of $355 \mathrm{~nm}$ and fulfilled eye-safety requirements. The overlap function of the lidar is equal to 1 at distances between 150 and $250 \mathrm{~m}$ from the emission. The emission comes from an Ultra ${ }^{\circledR}$ Nd:YAG laser manufactured by Quantel, delivering $6 \mathrm{~ns}$ width pulses at a repetition rate of $20 \mathrm{~Hz}$. The detection is carried out by photomultiplier tubes and narrowband filters with a bandwidth of $0.2 \mathrm{~nm}$. The signal acquisition is performed using PXI technology, manufactured by the National Instruments ${ }^{\mathrm{TM}}$ company (http://www.ni.com, last access: 15 March 2019), and using an acquisition board with a sampling rate of $200 \mathrm{MHz}$ corresponding to a lidar native vertical sampling of $0.75 \mathrm{~m}$. Note that the acquisition uses a pre-trigger for the correction of the sky background. This avoids effects related to potential variability in the baseline of analog-to-digital converters.

\subsection{Inversion scheme}

In order to retrieve the optical properties of aerosols transported in the free troposphere, we used an $\mathrm{N}_{2}$ Raman lidar system coupled with the sun photometer (e.g., Royer et al., 2011; Chazette et al., 2016) of the ToulonLa Garde AERONET (http://aeronet.gsfc.nasa.gov/, last access: 15 March 2019; level 2 data of version 3) site. Indeed, the signal-to-noise ratio (SNR) of the daytime lidar profiles is insufficient to use the $\mathrm{N}_{2}$-Raman channel as it presents a low emitted energy. Contrariwise, the $\mathrm{N}_{2}$-Raman channel was used during nighttime for the retrieval of the cumulative aerosol optical thickness (AOT). Combined with the elastic channel, this leads to the retrieval of the aerosol backscatter and extinction coefficients (ABC and AEC) and their ratio (Chazette et al., 2016). The backscatter-to-extinction ratio (BER) is equal to the product of the single-scattering albedo and of the probability of a photon being backscattered after an interaction between the laser flux and the atmospheric scatterers. It is the inverse of the lidar ratio (LR) often used in the literature. We prefer to consider the BER hereafter, which has a more direct physical meaning. The linear particle depolarization ratio (PDR) is also retrieved as in Chazette et al. (2012). Calculations are performed with a temporal resolution of at least $30 \mathrm{~min}$ and a vertical resolution of $30 \mathrm{~m}$ to improve the SNR in the middle troposphere (between 6 and 7 km a.m.s.l.).

Compared to the inversion scheme proposed in Chazette et al. (2016), in which an equivalent BER for the entire aerosol column is justified, the frequent presence of two aerosol layers, one in the marine boundary layer and the other in the free troposphere, led us to develop a multilayer inversion to independently evaluate the BERs of each aerosol layer and verify the relevance of the first approach, leading to an equivalent BER. This method builds on the case of a single aerosol layer described above. We begin by inverting the upper layer and determining its BER or LR, then we apply the same ap- 

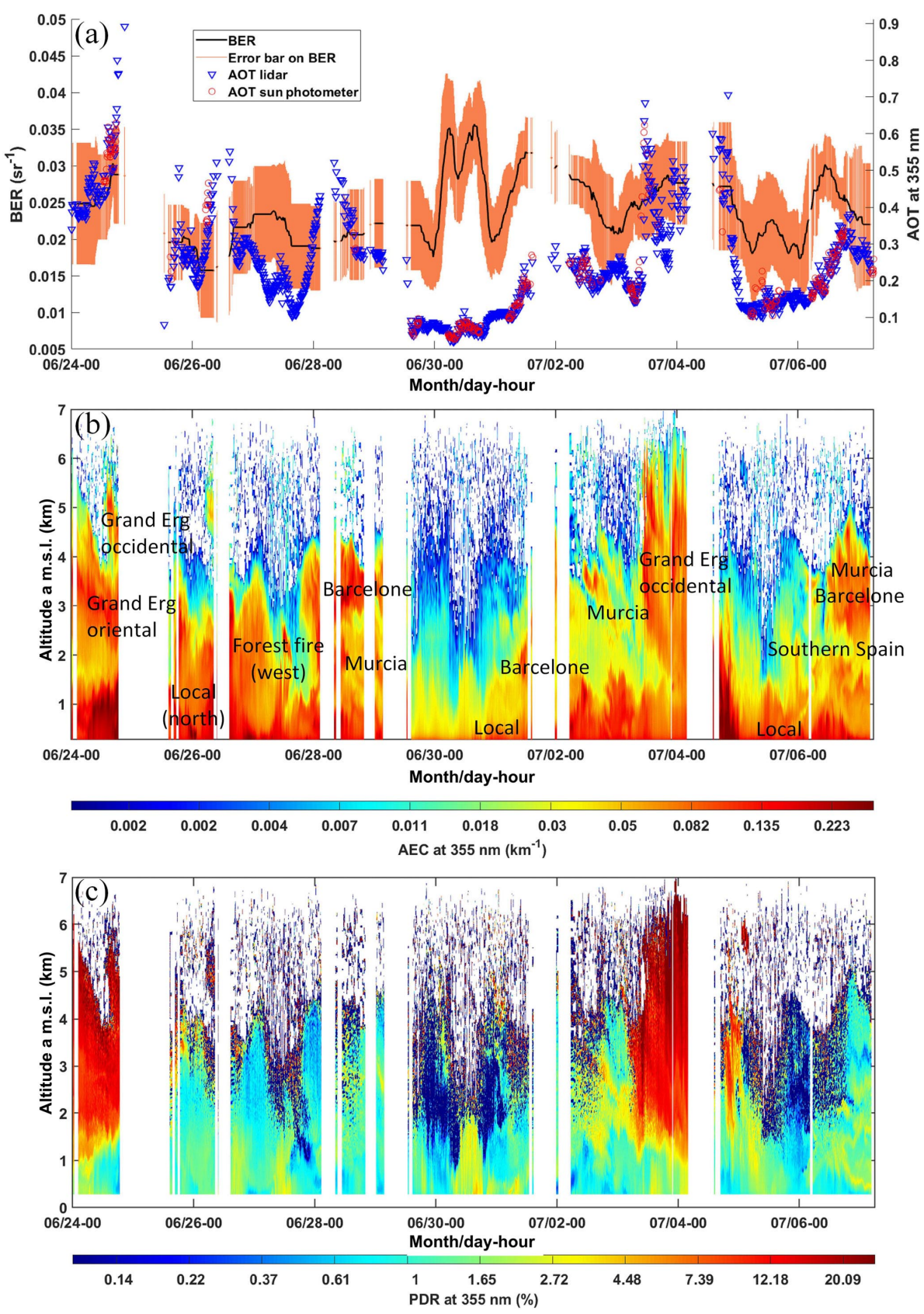

Figure 2. Temporal evolution (UTC) between 24 June and 7 July of (a) the backscatter-to-extinction ratio (BER; mean value as a black line and error bar in orange), as well as the aerosol optical thicknesses (AOT), at $355 \mathrm{~nm}$ derived from the sun photometer (red circles) and lidar measurements (blue triangle), (b) the vertical profile of the aerosol extinction coefficient (AEC) at $355 \mathrm{~nm}$, and (c) the vertical profile of the linear particulate depolarization ratio (PDR) at $355 \mathrm{~nm}$. White time stripes correspond to periods of low and middle clouds. The origins of the main aerosol plumes trapped in the free troposphere are indicated.

proach to the lower layer, retaining the LR of the higher layer. The constraint is given by the partial AOTs (Dieudonné et al., 2015) calculated from the $\mathrm{N}_{2}$-Raman channel for each of the aerosol layers previously located in altitude. The transition altitude between the layers is determined manually and the continuity is ensured by a sigmoid function on a thickness of about $1 \mathrm{~km}$ between the two layers. Such an approach is pos- sible, just like in the case of a single aerosol layer, if the SNR is larger than 10. This leads us to produce nighttime profiles with a time average of $5 \mathrm{~h}$ between 23:00 and 04:00 universal time count (UTC). 

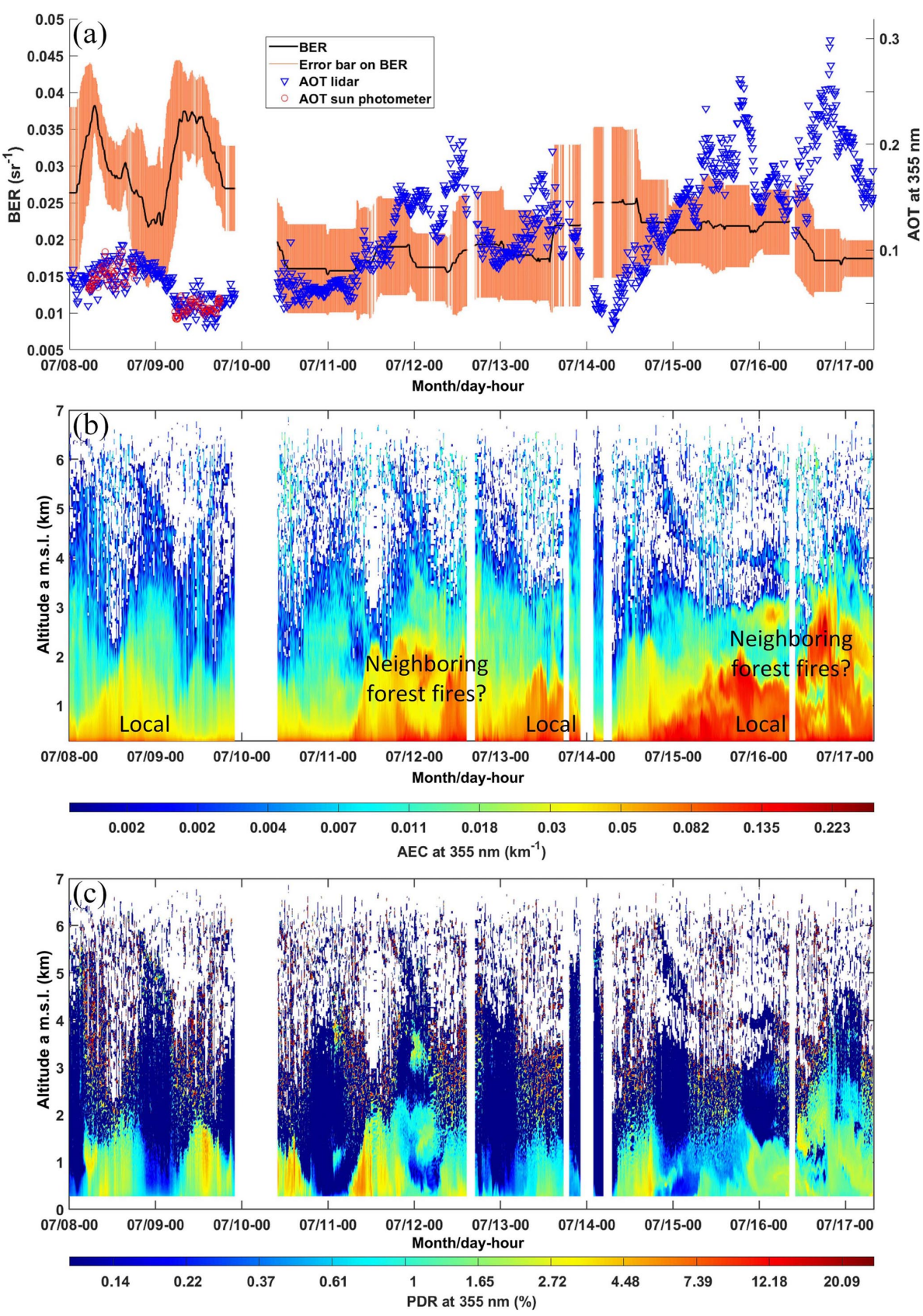

Figure 3. Same as Fig. 2 for the period between 8 and 17 July.

\subsection{Uncertainties}

The main uncertainty sources are discussed in Royer et al. (2011). The relative uncertainty in the $\mathrm{N}_{2}$-Raman-derived cumulative AOT is less than $2 \%$ for SNR $>10$. The uncertainty in the determination of the equivalent BER is in the range of $4-6 \times 10^{-3} \mathrm{sr}^{-1}(10-15 \mathrm{sr}$ in terms of LR). Such a value is very dependent on the SNR, which limits the exploitable range of the lidar profile, as shown in Table 2 of Dieudonné et al. (2017). The relative uncertainties in the
PDR are close to $10 \%$ for the AOTs encountered at $355 \mathrm{~nm}$ $(\mathrm{AOT}>0.2)$.

\section{Lidar observations}

\subsection{Temporal evolution}

The temporal evolution of the vertical profiles of optical parameters derived from lidar observations is shown in Fig. 2 and 3, separated into two periods: before and after 7 July. 


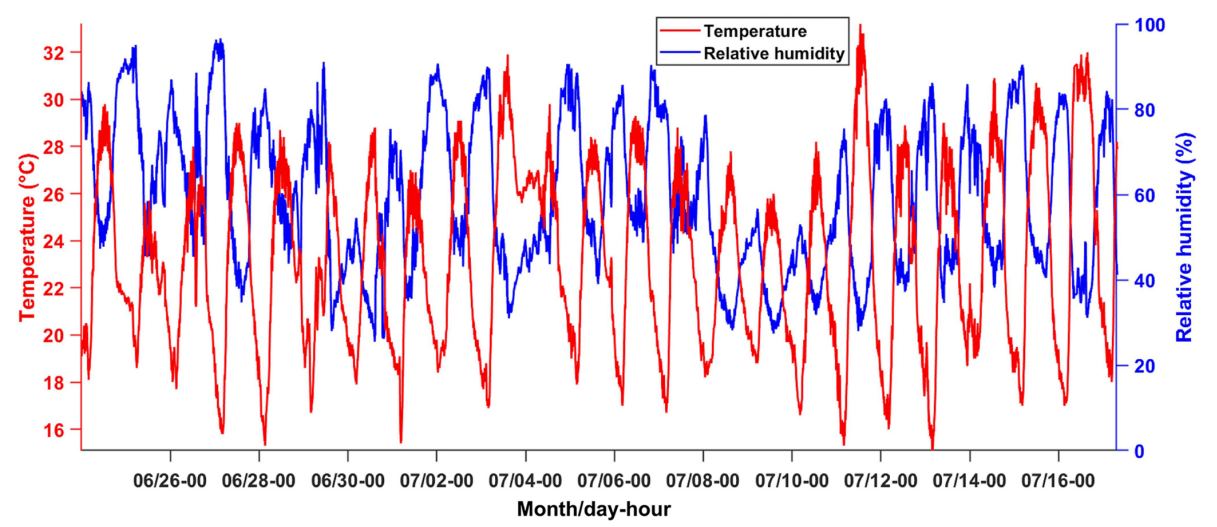

Figure 4. Temporal evolutions (UTC), from 4 June to 17 July 2014, of thermodynamic temperature and relative humidity at $2 \mathrm{~m}$ above the ground level.

Several days show anomalies of the aerosol load in the free troposphere, whereas others are more common, with a marked signature of the boundary layer cycle. The aerosol layers above $1.5 \mathrm{~km}$ a.m.s.l. are generally linked to longrange transport, especially on 24 and 28 June and 1-4 and 7 July (high values of AEC in Fig. 2b). Over the coastal site, aerosols within the planetary boundary layer (PBL) are mainly from local sources, either sea-spray aerosols generated by breaking waves (e.g., Yoon et al., 2007) or continental components arising from both natural and anthropogenic sources. The relative influence of these aerosol types is modulated by the land-sea breeze cycle (e.g., Piazzola et al., 2012).

The values of PDR are very variable, ranging between $\sim 1 \%$ and more than $20 \%$. These highest values are observed in the free troposphere on 24 June and 3-4 July and may be associated with plumes of terrigenous aerosol with nonspherical shapes. In the PBL, we note the existence of vertical streaks, which are the signature of thermal updrafts developing during the day. They can lift local terrigenous particles and even pollen to the PBL top. The PDR is greater, but not very high inside these structures ( $2 \%-3 \%)$. Indeed, these aerosols are most probably mixed with a significant quantity of spherical hygroscopic particles from the sea or from local pollution.

Relatively high AOTs are measured over much of the observation period, with values exceeding 0.2 at $355 \mathrm{~nm}$ and peak values greater than 0.5 . AOT values below 0.2 correspond to undisturbed periods, i.e., without the presence of aerosol layers in the free troposphere. Hereafter, days are tagged as disturbed with an aerosol charge anomaly in the free troposphere or as undisturbed in the contrary case. It should be noted that, during the second period of the measurement campaign, there is no significant aerosol load in the free troposphere. During the first period (24 June to 7 July), it is rather the opposite, except from 30 June to 1 July. These two days are grouped together with those of the second period in our analysis. Moreover, these two days show a very strong variation in the BER along time as is the case in the beginning of the second period, from 8 to 10 July $\left(0.020 \mathrm{sr}^{-1}\right.$ during nighttime and $0.035 \mathrm{sr}^{-1}$ during daytime). These days are associated with low relative humidity at the ground level: below $50 \%$, as shown in Fig. 4. The liquefaction point of the soluble compounds trapped on the aerosol was therefore probably not reached (e.g., Randriamiarisoa et al., 2006). The strong variations in BER are certainly attributable to the local breeze regime with a stronger marine contribution during the day and therefore larger aerosols. The daytime value is similar to that found by Flamant et al. (1998), which was $\sim 0.040 \mathrm{sr}^{-1}$ for marine boundary layer aerosols close to the Azores.

\subsection{Variability along the altitude}

Before proceeding further, we will check whether or not the hypothesis of a constant BER in the whole atmospheric column is justified. An easy way to verify this is to compare the results for the profiles of the cumulative AOT derived from the inversion of the elastic channel and the one from the $\mathrm{N}_{2}-$ Raman channel as in Chazette et al. (2017): the selected BER value is close to the real one if the two profiles coincide.

Here, the two-layer method described in Sect. 2.2 is applied for nighttime lidar profile inversion. The profiles of cumulative AOT for the main cases of the campaign are given in Fig. 5. We noticed that BER values in the lowermost layers $\left(0.024 \mathrm{sr}^{-1}\right)$ are only significantly different to the ones found in the upper aerosol layers $\left(0.031 \mathrm{sr}^{-1}\right)$ in the case of 24 June. On the same day, the retrieved column-equivalent BER ranges between 0.017 and $0.033 \mathrm{sr}^{-1}$, with a mean value of $0.027 \mathrm{sr}^{-1}$. Taking uncertainties into account, these values overlap. We can, however, expect an error in total AOT of about $15 \%$ to $20 \%$. For the other nights, the hypothesis of one column-equivalent BER value is reasonable, although the nature of aerosols can be different between layers. In our case, there is a strong anthropic component associated with the marine aerosols over the measurement site (Piazzola et 

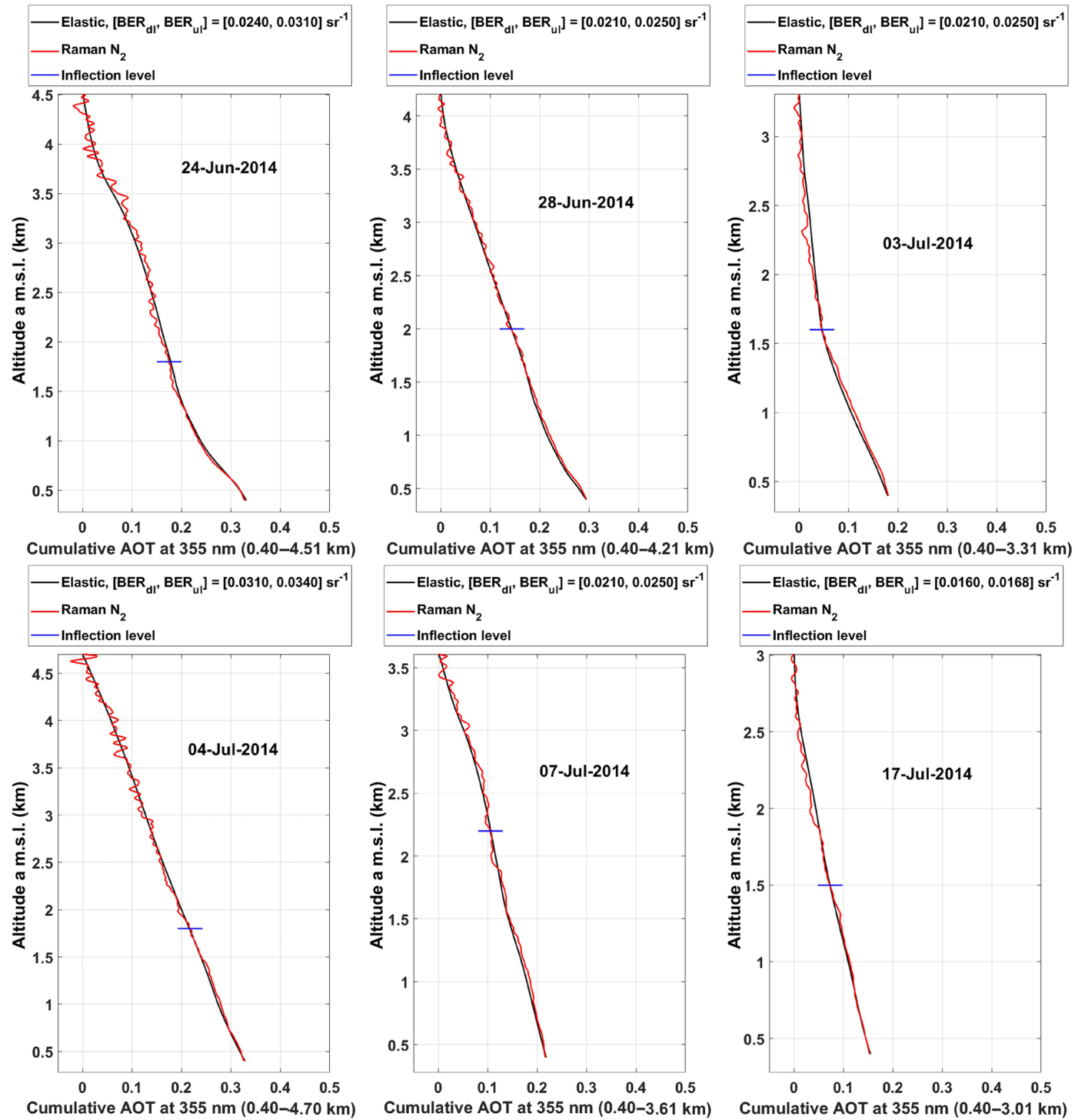

Figure 5. Vertical profiles of the cumulative aerosol optical thickness (AOT) for six different nights. The lidar profiles are time-averaged between 23:00 UTC the previous day and 04:00 UTC the next day. The inflection levels between the two main aerosol layers are highlighted by a horizontal blue line for each night. The backscatter-to-extinction ratios (BERs) are given in the legends in parentheses for the lower $\left(\mathrm{BER}_{\mathrm{dl}}\right)$ and upper $\left(\mathrm{BER}_{\mathrm{ul}}\right)$ aerosol layers.

al., 2012). These aerosols being hydrophilic, both their size and their complex refraction index can change significantly between the PBL and the free troposphere (Randriamiarisoa et al., 2006). Nevertheless, the work of Raut and Chazette (2008a) has shown that a variation in relative humidity does not significantly modify the value of BER for traffic aerosols. Here, the low vertical variability in BER supports these findings, given that the relative humidity in the PBL was mainly above $80 \%$, whereas it was below $50 \%$ in the free troposphere.

In addition, the study of correlation matrices computed from the AEC profiles between altitudes for (i) the whole duration of the campaign and (ii) for the undisturbed period shows that there are correlated aerosol plumes between the PBL and the free troposphere, which can be due to the transfer of aerosols between these two layers. Figure 6 gives a graphical representation of the magnitude of the coefficients in the matrices of both the entire measurement period, between 24 June and 17 July 2014, and the non-perturbated period. For undisturbed cases (Fig. 6a), the correlation distance, calculated as the distance over which the correlation coefficient is greater than 0.6 , does not exceed $\sim 2 \mathrm{~km}$, whereas it largely exceeds $3 \mathrm{~km}$ when averaged over the whole duration of the campaign. This argues for the conclusion that during transport events in the low free troposphere, aerosols may be transferred into the PBL. Simultaneous transport be- 

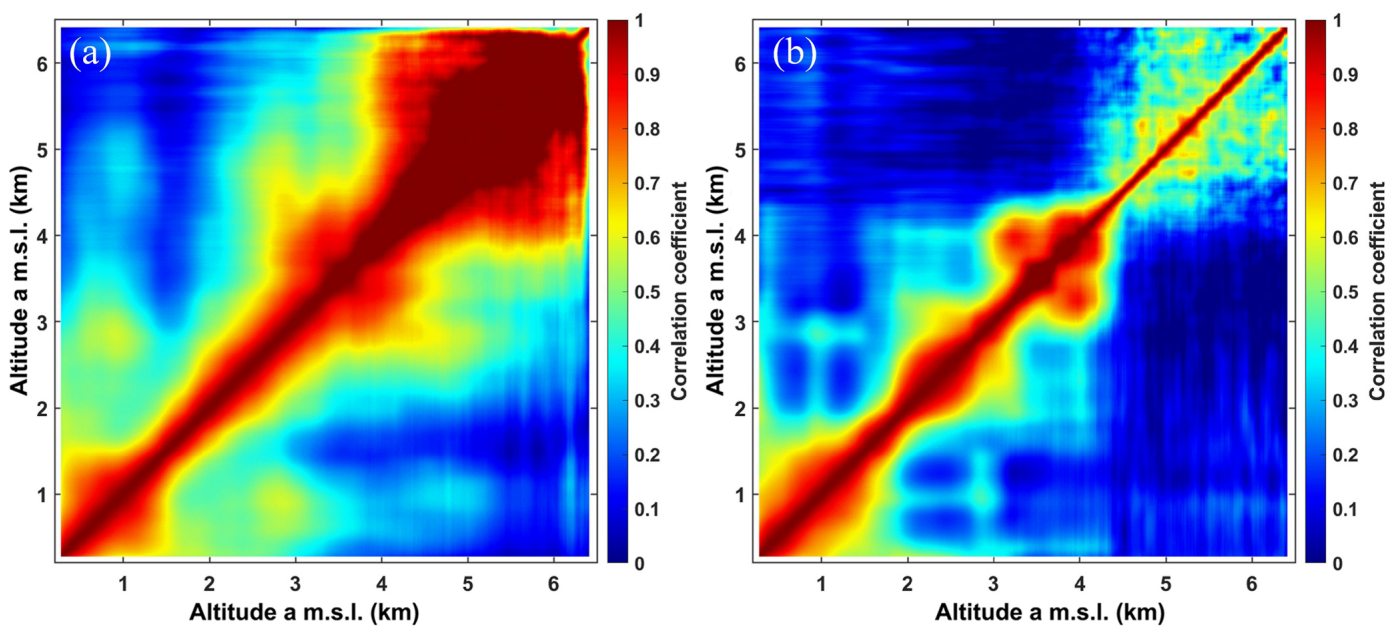

Figure 6. Lidar-derived correlation matrices for (a) the entire measurement period, between 24 June and 17 July 2014 , and (b) the undisturbed period (without aerosol load anomaly in the free troposphere). These matrices are symmetric by construction.

tween the marine boundary layer and the free troposphere is unlikely over the large distance separating the emission and the arrival of the aerosol plumes over the French Riviera. The most relevant hypothesis is that the recirculation of air masses along the seashore due to relief and a modification of average winds in the PBL between undisturbed and disturbed cases explain these transfers. Furthermore, large correlation distances are found in the middle free troposphere (Fig. 6b), where aerosol plumes have been transported over a long distance. For undisturbed situations above $5.5 \mathrm{~km}$ a.m.s.l., the patchiness of the data is due to the relatively high noise when aerosol scatterer is almost absent.

\section{Meteorological conditions}

Wind conditions control the transport of aerosols above the French Riviera. To analyze the meteorological conditions during the field campaign over our observation site of Toulon, we use the ERA5 reanalyses (https://www.ecmwf.int/en/forecasts/datasets/ archive-datasets/reanalysis-datasets/era5, last access: 15 March 2019) with a horizontal resolution of 0.25 or $0.30^{\circ}$. This dataset is provided by the European Centre for Medium-Range Weather Forecasts integrated forecast system (ECMWF), developed through the Copernicus Climate Change Service (https://climate.copernicus.eu/, last access: 15 March 2019).

Figure 7 shows the wind direction distribution, computed from ERA5 data for the measurement site, at the $975 \mathrm{hPa}$ level ( $\sim 0.4 \mathrm{~km}$ a.m.s.l.) during the disturbed (Fig. $7 \mathrm{a})$ and undisturbed cases (Fig. 7b). For the undisturbed cases, the majority of winds come from the northwest, and there is little marine contribution. We therefore do not observe a marked see-land breeze cycle at the model resolution. In this configuration, one can expect the influence of pollution sources to be linked to road traffic, which is intense in the summer season just north of the measurement site, or of possible biomass fires that are very frequent in the backcountry at this period. For disturbed cases, the origin of winds near the surface is much more diverse and reflects the breeze cycle with a significant marine contribution from the south sector during the day and dominant winds from the east or west along the coast. The northwest component is still present in the disturbed cases but much less frequent. In the lower free troposphere, there are also strong differences between disturbed and undisturbed situations. Figure 8 presents wind distributions at the $700 \mathrm{hPa}$ level ( $3 \mathrm{~km}$ a.m.s.l.). For undisturbed cases (Fig. 8b), winds are predominantly from the northnorthwest. It is much less distinct during disturbed cases, and presumably multiple contributions are observed from the west-northwest, west-southwest, and south-southwest. The different potential contributions are explained hereafter.

On a larger scale, the circulation of air masses advected over the western Mediterranean mostly depends on the relative positions of the Azores and Siberian highs. It is strongly modulated by lows traveling east over midlatitudes. Depending on the position of these lows, air masses from the Atlantic (over Gibraltar) and from the Sahara can reach the western Mediterranean coast. Figure 9 gives an illustration of the two different configurations predominantly encountered during the measurement campaign.

In Fig. 9a, the meteorological situation of 24 June is presented for level $700 \mathrm{hPa}$ in the ERA5 reanalyses. It corresponds to elevated values of PDR in the lower free troposphere (Fig. 2c). Tropical air masses are channeled by the presence of two highs, one over the North Atlantic (Azores high) and the other over the Sahara, as well as a weak low over the Iberian Peninsula and a strong low over Scandinavia. This configuration favors the transport of desert dust aerosols over the Mediterranean Sea (Hamonou et al., 1999). It is re- 

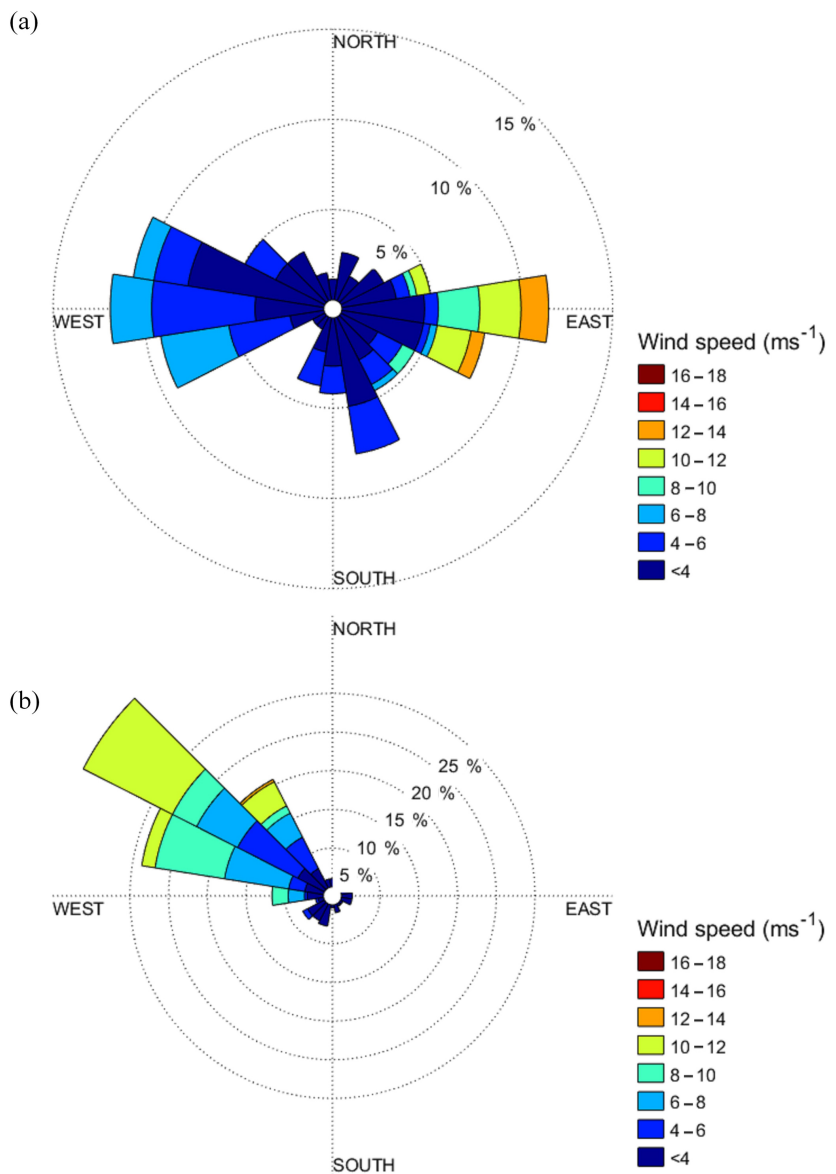

(b)

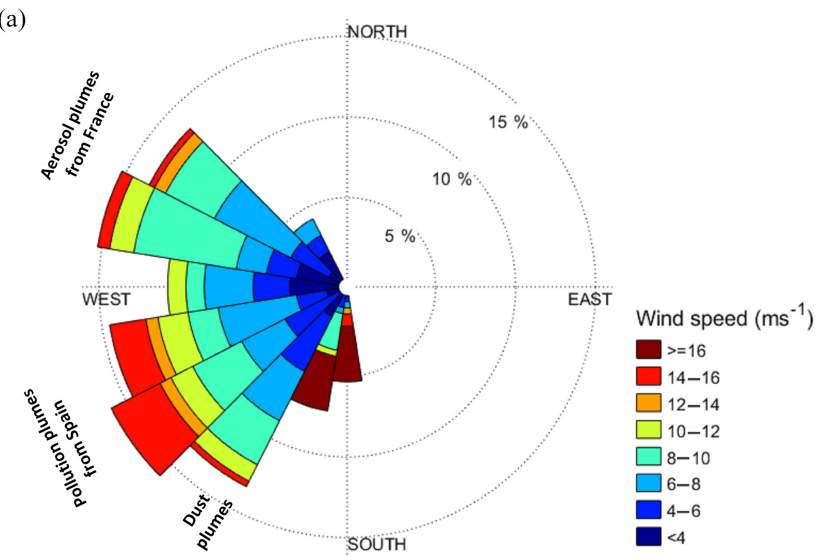

Figure 7. Frequency of counts (\%) by wind speed direction at $975 \mathrm{hPa}(\sim 0.4 \mathrm{~km}$ a.m.s.1.) for (a) disturbed cases, which are days with aerosol anomaly within the free troposphere, and (b) undisturbed cases, which are days without anomaly. The hourly data are from the ERA5 reanalyzes at $0.25^{\circ}$ of horizontal resolution and at the closest grid point from the station.

peated on 3-4 July, when strong PDR values are also observed. Concerning the aerosol plumes observed on 1, 2, and 4 July (Fig. 2b), we found a displacement towards the British Isles, a strengthening of the low near Iceland (Fig. 9a), and a weakening of the low near Scandinavia. Tropical air masses are then deviated towards Sardinia, and air masses from the eastern Spanish coast are more often advected above the marine boundary layer, which explains the significant PDR decrease in the observed aerosol layers.

The second typical meteorological situation is illustrated in Fig. $9 \mathrm{~b}$ for 28 June. It shows an Atlantic circulation mostly driven by the location of the low over the British Isles and Scandinavia. This circulation favors the arrival of air masses from the Spanish coast over the French Riviera area. The situation is very similar on 7 July, with a deepening of the low on the British Isles and a high in the Baltic countries. 

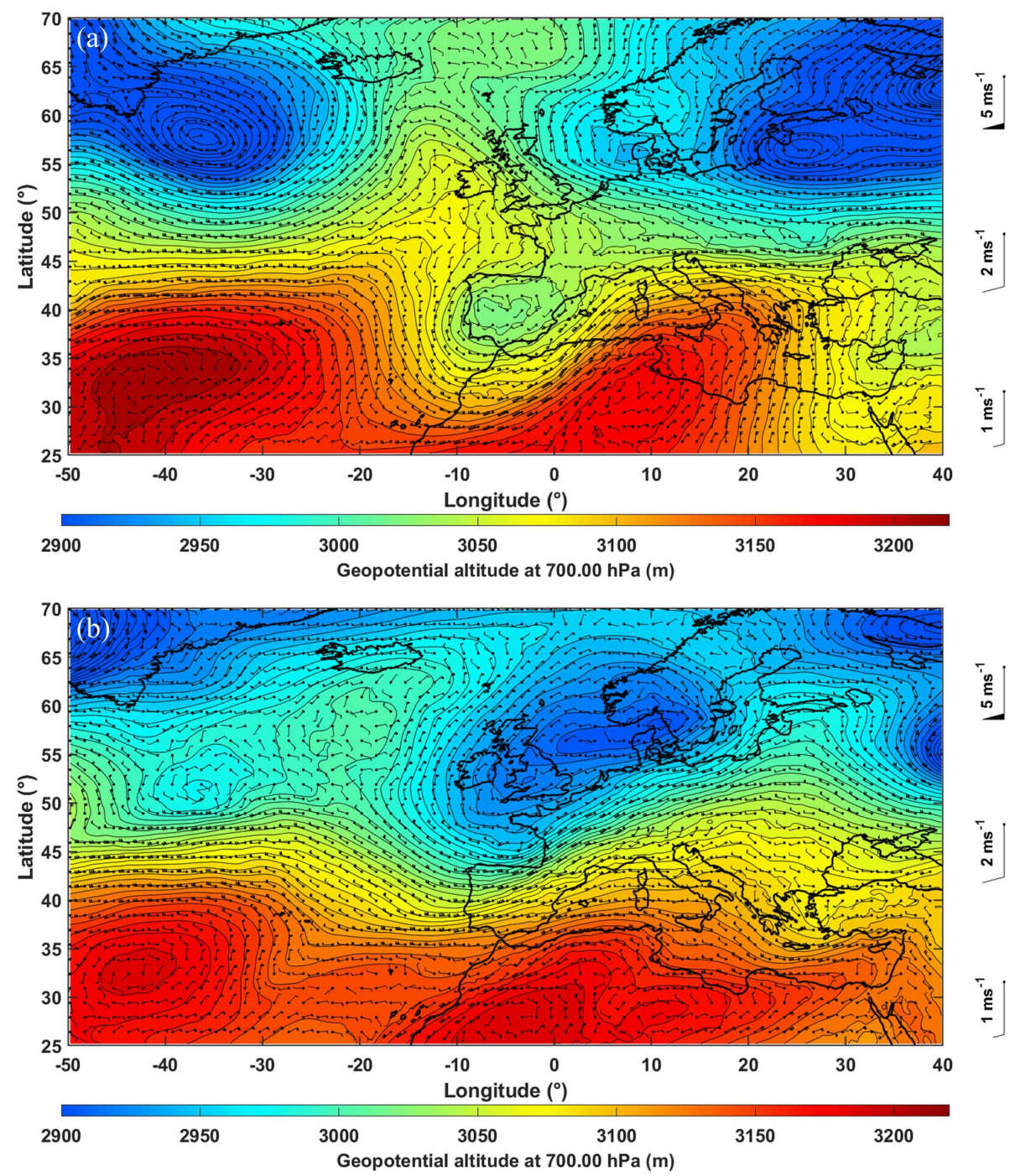

Figure 9. Geopotential altitude from the ERA5 reanalyses given for the pressure levels of 700 hPa at 12:00 UTC on (a) 24 and (b) 28 June 2014. The wind field is also shown in each panel. The horizontal resolution is $0.30^{\circ}$.

(http://www.ncep.noaa.gov/, last access: 15 March 2019) at $0.5^{\circ}$ horizontal resolution and works in its ensemble mode; i.e., 27 back trajectories are computed for each end location. The end points of the back trajectories are defined using the lidar profiles in Fig. 2 or 3 to determine both their temporal and altitude locations above the lidar. The origin of the aerosol plumes trapped in the free troposphere is highlighted in Fig. $8 \mathrm{a}$ and discussed hereafter.

\subsection{Spain's contribution}

It is between 28 June and 7 July that aerosol plumes with low depolarization have been observed in the free troposphere (see Fig. 2), mostly on 28-29 June and 6-7 July. The study of back trajectories shows that most of these plumes originate from the Spanish Mediterranean coast (Fig. 10). They take about 1 day to reach the western part of the French
Riviera. We have identified two main contributing regions on the Spanish coast: the region of Barcelona (Costa Brava and Costa Daurada) and the region of Murcia (Costa Blanca). The origins of the plumes are indicated at $700 \mathrm{hPa}$ on the wind rose in Fig. 8a and Fig. 2b and also take into account pollution plumes of weaker magnitude. The contributions of the different sources observed above the French Riviera are not systematically mixed when arriving above the lidar site but are frequently separated over different altitudes. For this reason, back trajectories starting at different altitudes have been performed for the same day. On 28 June, the aerosol plume in the lower free troposphere, around $2 \mathrm{~km}$ a.m.s.l., is predominantly from the Murcia region (Fig. 10a). AOT values above 0.4 were recorded at $355 \mathrm{~nm}$ wavelength by the local AERONET station of Murcia 2 days prior. The aerosol plumes originating from the region of Barcelona are 

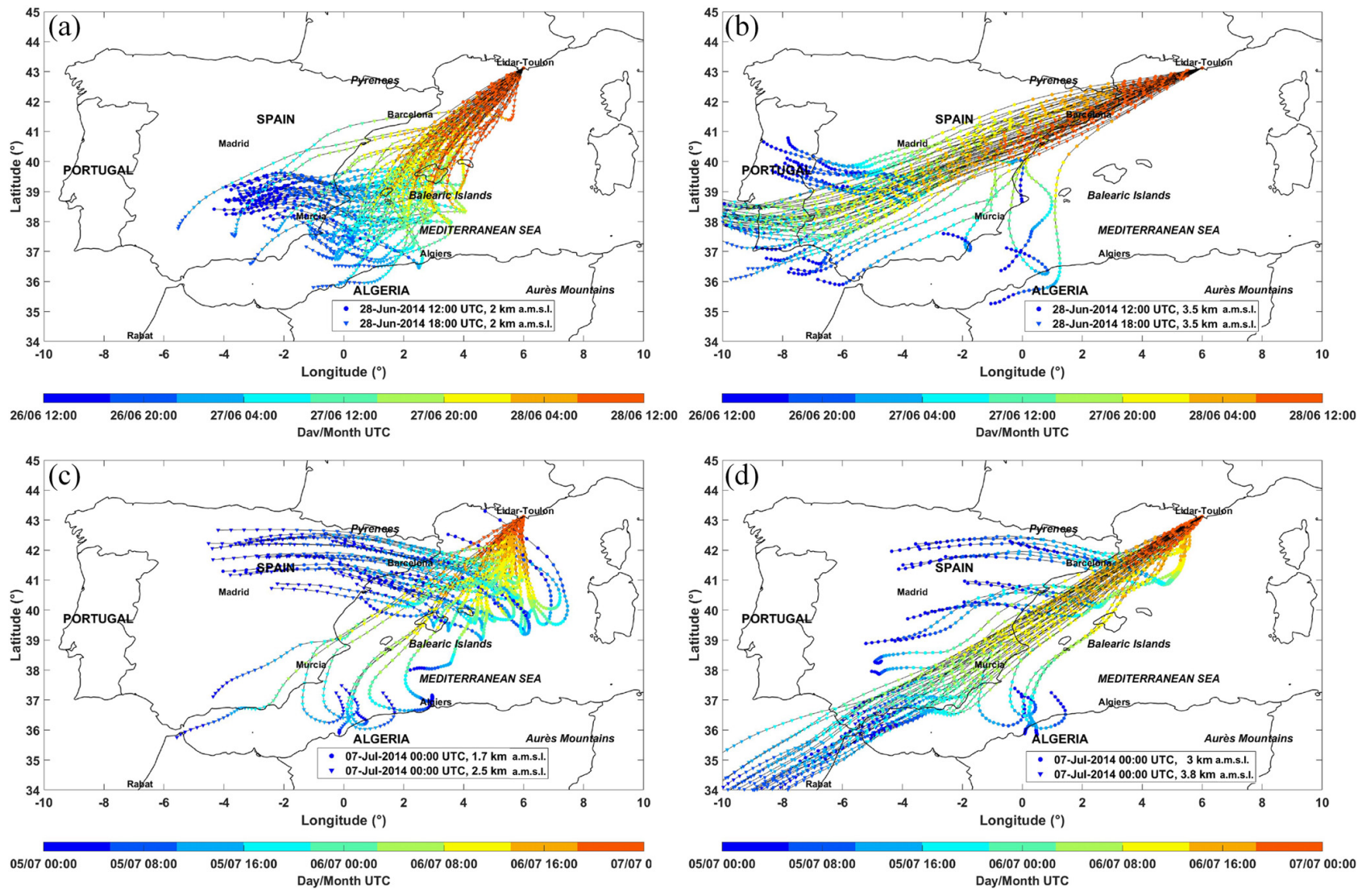

Figure 10. 2-day back trajectories from the French Riviera (Toulon; $43.13556^{\circ} \mathrm{N}, 6.00944^{\circ} \mathrm{E}$ ). The altitudes of the end locations of the air mass trajectories are in the main pollution plumes detected by the ground-based $\mathrm{N}_{2}$-Raman lidar on (a) 28 June 2014 for an end location of $2 \mathrm{~km}$, (b) 28 June 2014 for an end location of $3.5 \mathrm{~km}$, (c) 7 July 2014 for end locations of 1.7 and $2.5 \mathrm{~km}$, and (d) 7 July 2014 for end locations of 3 and $3.8 \mathrm{~km}$. The HYSPLIT model worked in its ensemble mode, i.e., 27 back trajectories computed for each end location.

mostly observed at higher altitude, around $3.5 \mathrm{~km}$ (Fig. 10b), with similar local AOTs. The visible Ångström exponent is characteristic of pollution aerosols with values over 1.5. The aerosol plume on 7 July originates from the same regions, but with a contribution from Barcelona in the lower free troposphere (Fig. 10c), with local AOTs at $355 \mathrm{~nm}$ around 0.3 2 days prior, and Ångström exponent values close to those of the previous case. The contribution of the Murcia region starts a day earlier and at a higher altitude (Fig. 10d), with similar AOTs and Ångström exponents.

The AOT fields at $550 \mathrm{~nm}$ derived from MODIS observations are presented in Fig. 11 for the two main dates with aerosol plumes in the free troposphere. The main contributing areas are located around Barcelona and specifically around Murcia, where AOTs above 0.4 are observed. Note that no major forest fire could be identified in the Iberian Peninsula from the MODIS fire product (https://ladsweb. modaps.eosdis.nasa.gov/search/, last access: 15 March 2019) during the whole measurement period. In Barcelona, road traffic is the foremost cause of pollution, with an urban conglomerate of more than 1.6 million inhabitants (Dall'Osto et al., 2012). Emissions linked to the automobile indus- try, petrochemistry, and shipping activity also contribute in this area. As for Murcia, it is a conglomerate with more than 700000 inhabitants, on which traffic also has a nonnegligible impact, but cannot single-handedly explain the strong signature seen on the MODIS AOT map. It is also a region with intense agriculture, which has been dubbed "Europe's orchard"; nonetheless, the June period is not suitable for slash-and-burn agriculture or muck spreading. However, the locality of Escombreras, near Cartagena in the southeast of Murcia, includes a gigantic seaside oil processing complex with a refinery and a harbor. This area can therefore be a strong emitter of aerosol precursors. Without considering the desert dust episodes, we confirmed that MODIS observations often show AOT values above 0.6 in the south of Murcia during summertime (https://worldview.earthdata.nasa.gov, last access: 15 March 2019). A mix of traffic and industrial emissions can certainly explain the plume observed over Murcia, part of which is transported towards the French Riviera.

There are no CALIOP observations of the Barcelona area. Conversely, there are daytime and nighttime orbits overflying the region of Murcia, yet none of these orbits are exploitable during the campaign, as they are mostly associated 
(a)
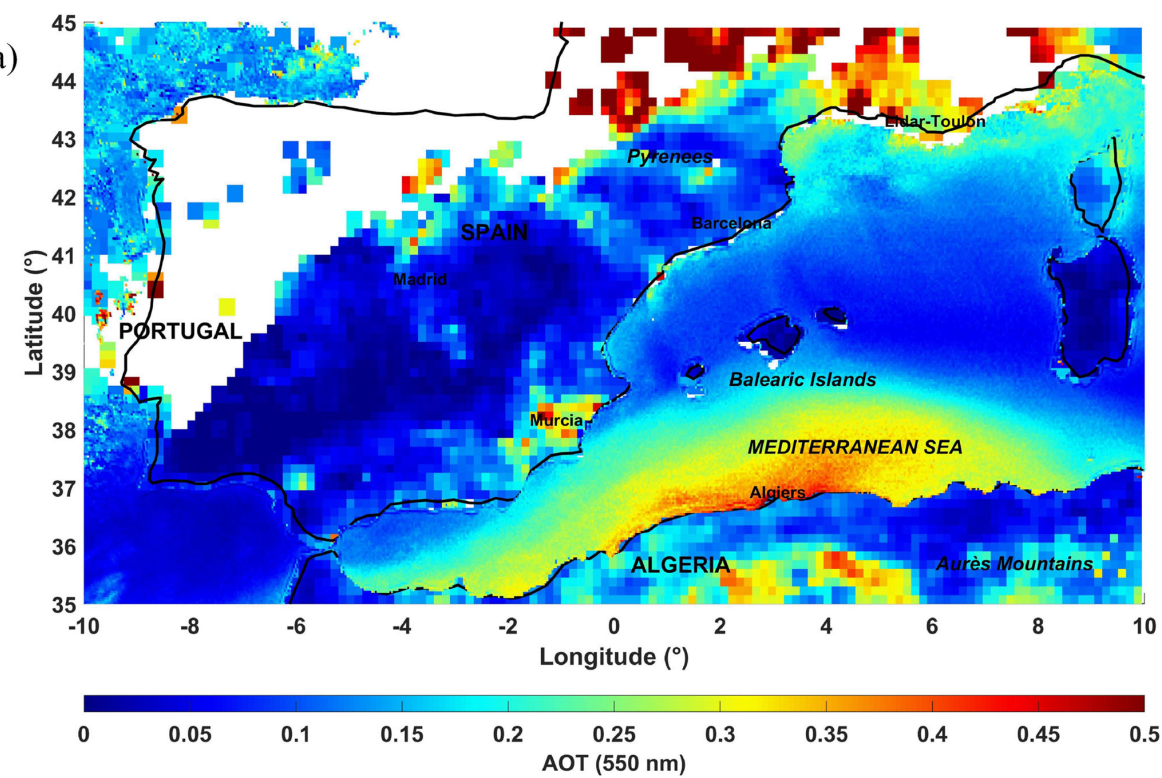

(b)

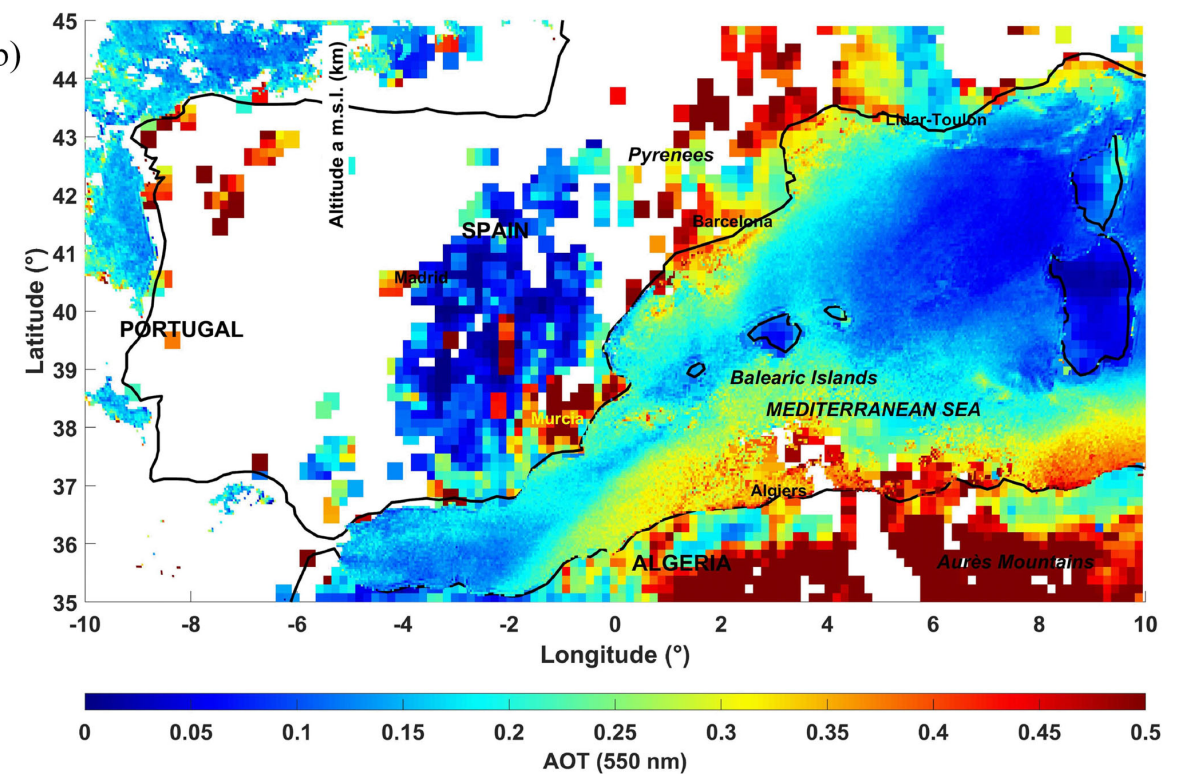

Figure 11. AOT at $550 \mathrm{~nm}$ derived from the composition of MODIS over land and SEVIRI over sea observations: (a) on 28 June 2014 and (b) on 6 July 2014.

with desert dust episodes, which are very frequent in the region. Local aerosols therefore cannot be isolated with good accuracy. In order to obtain the CALIOP classification of the aerosols emitted in the Murcia region (Burton et al., 2013), we have thus extended our search for a coincident nighttime orbit until August. The choice of a nighttime orbit is motivated by the need for a higher signal-to-noise ratio. The only day in summer 2014 when CALIOP overflew Murcia and local aerosols were recorded is 25 August. Figure 12 presents the MODIS image and the corresponding CALIOP orbit. The two observations are $12 \mathrm{~h}$ apart. The MODIS-derived AOT values are close to those in Fig. 11. The CALIOP aerosol classification scheme indicates mostly polluted dust with a BER of $0.018 \mathrm{sr}^{-1}(\mathrm{LR}=55 \mathrm{sr})$, matching the values identified in the aerosol plumes from the ground-based lidar (Fig. 5).

The pollution plumes from Barcelona and Murcia can be injected into the free troposphere when the warm continental air mass is advected over the colder water of the Mediterranean Sea. This process can lead to the injection of pollution aerosols up to altitudes exceeding $4 \mathrm{~km}$ a.m.s.l., as observed in Fig. 2b. Such plumes can then be seamlessly transported towards and above the French Riviera. These pollution particles are finally eliminated mostly by rainfall and 


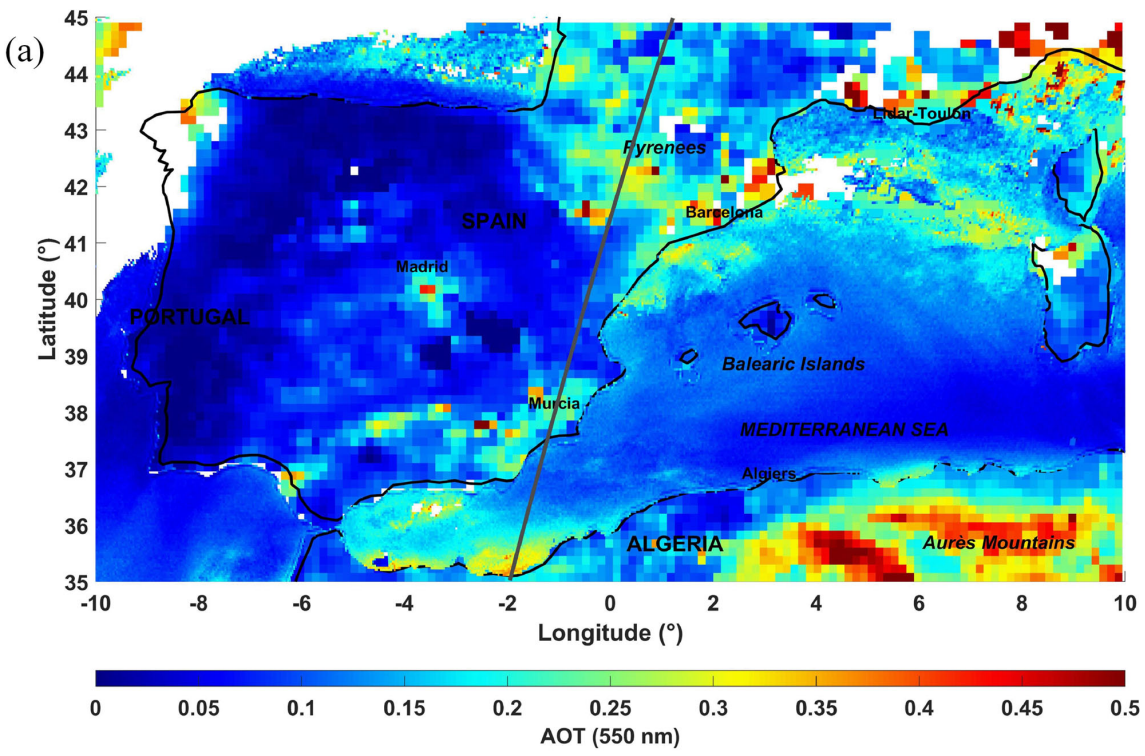

(b)

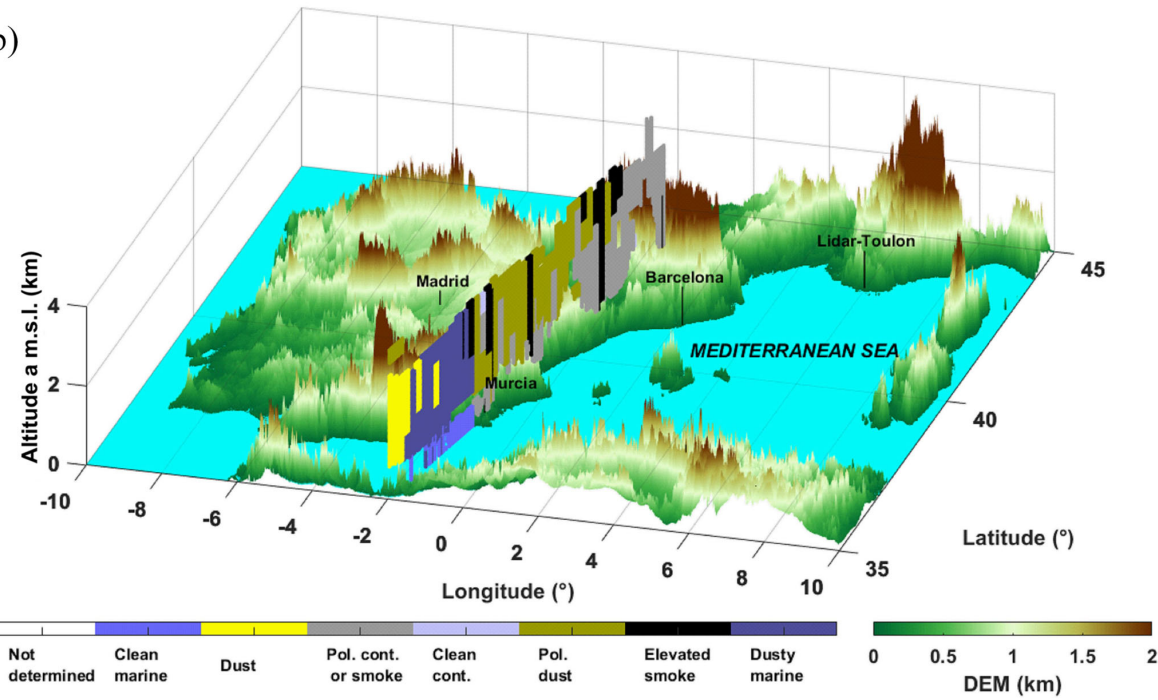

Figure 12. (a) AOT at $550 \mathrm{~nm}$ derived from the composition of MODIS over land and SEVIRI over sea observations on 25 August 2014. The nearest nighttime ( 02:15 UTC) ground tracks of CALIOP are given as dark grey continuous lines. (b) CALIOP-derived aerosol typing (version 4.10) as observed on August 2014. DEM: digital elevation model.

will reach the surface and water streams. The probable presence of black carbon, as identified by Chrit et al. (2018), will favor the trapping of solar energy in the aerosol layer and induce local heating, which is known to modify the balance of the low and middle troposphere (e.g., Raut and Chazette, 2008b).

\subsection{Northern Africa contribution}

Desert dust aerosol transport is rather frequent during May and June above France and decreases in frequency over July, while remaining probable (Israelevich et al., 2012). In itself, it is not extraordinary to observe such events during a field campaign with a duration of about 1 month. The lifting zones located in the Sahara are variable, depending on the westeast travel of lows over the Mediterranean basin (Hamonou et al., 1999). Here, we describe the two events sampled by the ground-based lidar, as highlighted by the high PDR values in Fig. 2c. This will allow us, among other aspects, to evaluate the degree of coherence between the observations of the spaceborne lidar CALIOP and the ground-based lidar in the French Riviera.

The 3-day back trajectories in Fig. 13 highlight the probable sources of terrigenous aerosols, which are the Grand Erg Occidental (between Morocco and Algeria) and the Grand Erg Oriental (southwest of Tunisia). The contributions of these two sources can be superimposed in altitude (Hamonou et al., 1999). The plumes partly sampled by the ground-based 
(a)

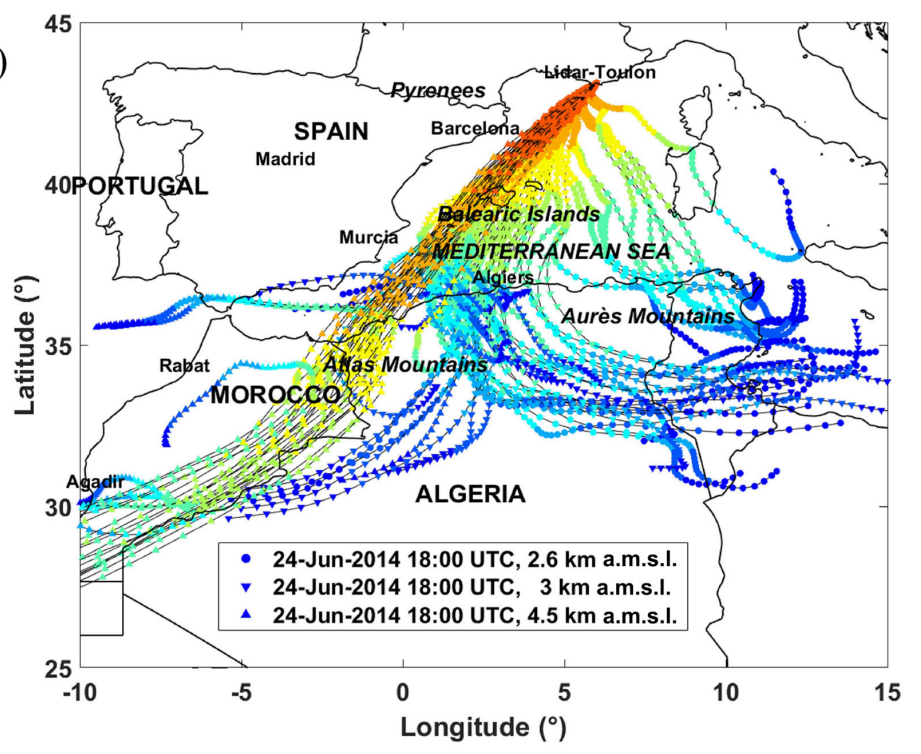

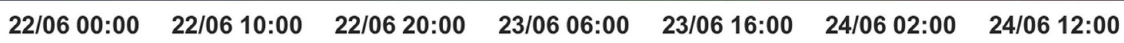

Day/month UTC

(b)

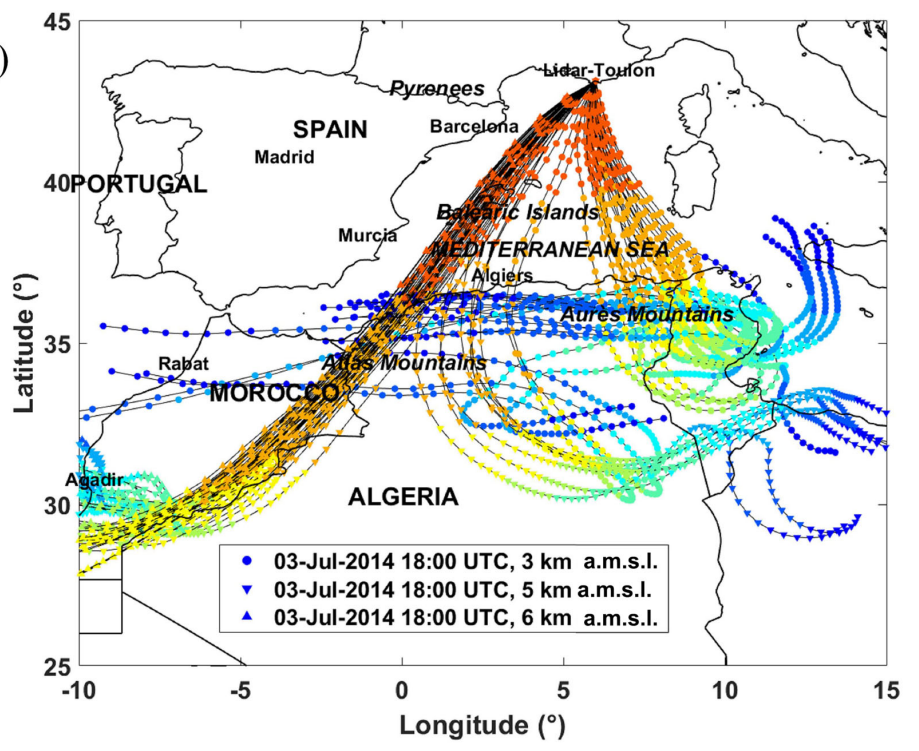

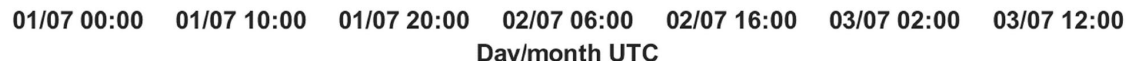

Figure 13. 3-day back trajectories from the French Riviera (Toulon; $43.13556^{\circ} \mathrm{N}, 6.00944^{\circ} \mathrm{E}$ ). The altitudes of the end locations of the air mass trajectories are in the main dust plumes detected by the ground-based $\mathrm{N}_{2}$-Raman lidar on (a) 24 June 2014 for end locations of $2.6,3$, and $4.5 \mathrm{~km}$, (b) 3 July 2014 for end locations of 3, 5, and $6 \mathrm{~km}$. The HYSPLIT model worked in its ensemble mode, i.e., 27 back trajectories computed for each end location.

lidar are also shown on MODIS and SEVIRI AOT observations in Fig. 14. They are intense events, with AOTs at $550 \mathrm{~nm}$ exceeding 1 along the African coast. Dispersion will decrease the AOT during transport, leading to values around 0.5 to 0.6 when reaching the French Riviera. These values match the sun photometer measurements of the AERONET station of Toulon-La Garde on 24 June. The comparison is difficult for the second plume happening during the night of 3-4 July; however, there could be an overestimation of AOT of about 0.15 by the satellite compared to the sun photometer. During nighttime, the calculation of AOT is possible with the lidar thanks to its $\mathrm{N}_{2}$-Raman channel and yields AOT values 
(a)

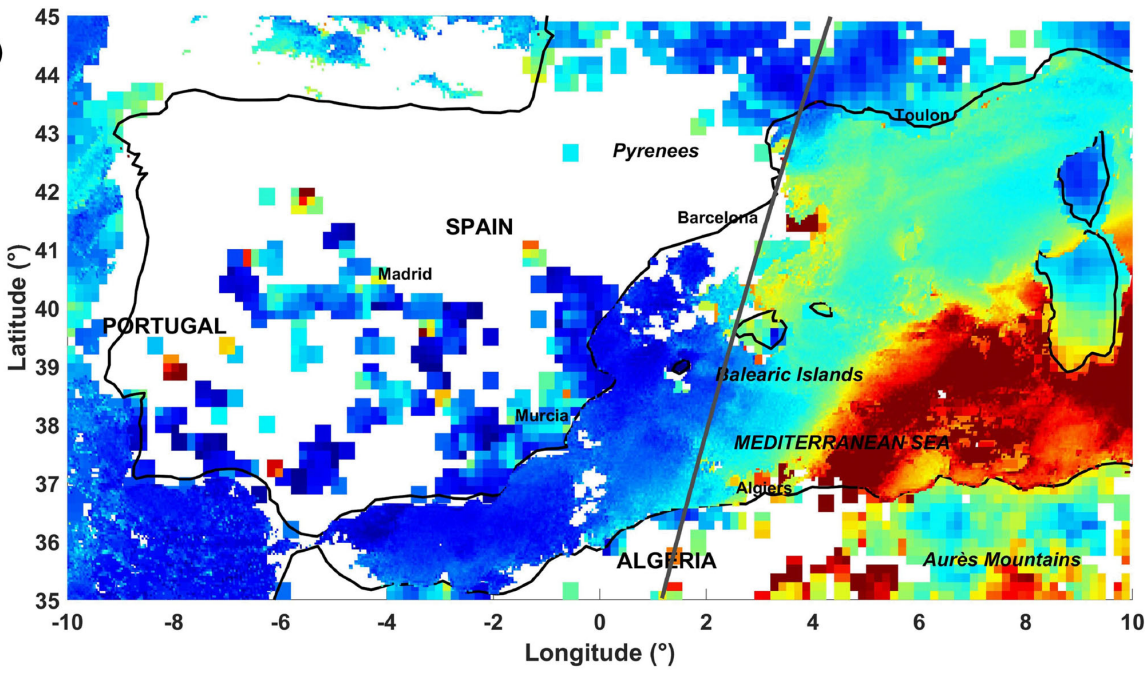

\begin{tabular}{lllllllllll}
\hline 0 & 0.1 & 0.2 & 0.3 & 0.4 & 0.5 & 0.6 & 0.7 & 0.8 & 0.9 & 1 \\
AОT $(550 \mathrm{~nm})$ &
\end{tabular}

(b)

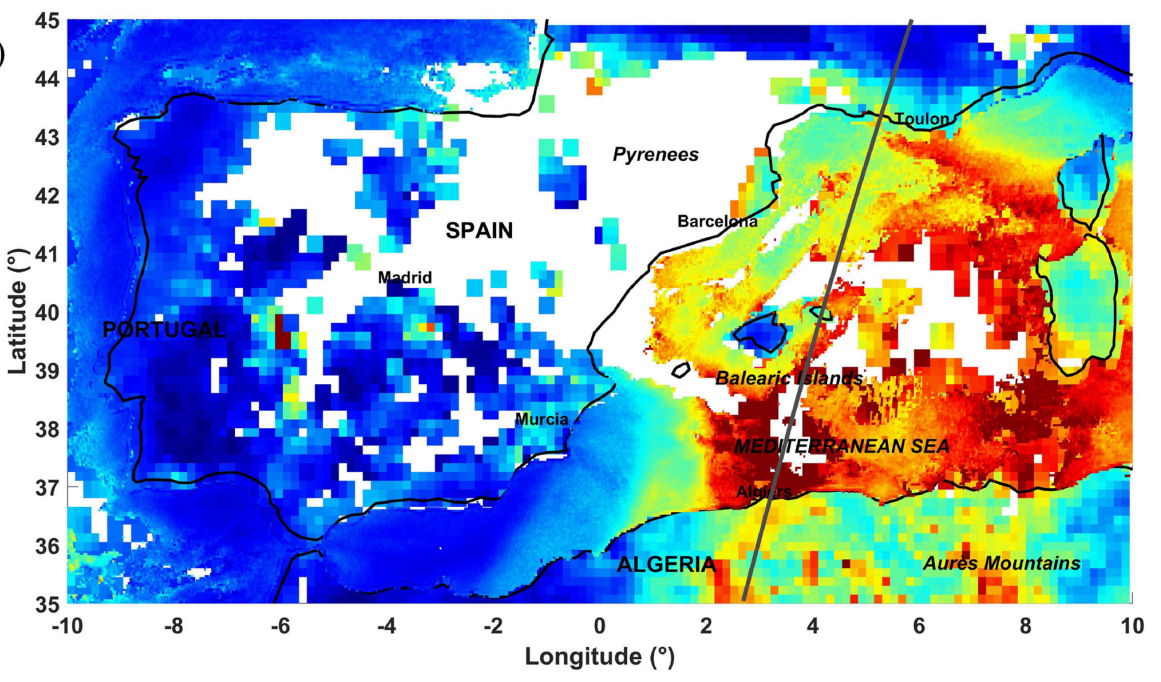

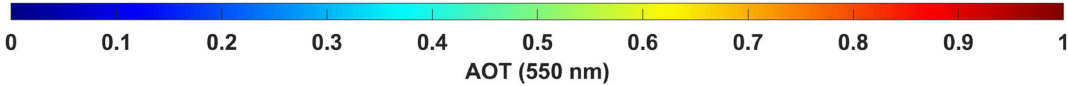

Figure 14. AOT at $550 \mathrm{~nm}$ derived from the composition of MODIS over land and SEVIRI over sea observations: (a) on 24 June 2014 and (b) on 3 July 2014. The nearest nighttime ( 02:00 UTC) ground tracks of CALIOP are given as dark grey continuous lines.

of $\sim 0.5$ at $550 \mathrm{~nm}$, when assuming a 0.8 Ångström exponent for the spectral variation of the AEC.

We have at our disposal, for each of these two dust aerosol events, a single nighttime CALIPSO orbit passing close to the lidar site. These orbits are traced in Fig. 14. The aerosol classification given by version 4.1 of the CALIOP operational algorithm is shown in Fig. 15. Note that the plume must have moved between the observations of CALIOP and MODIS since they are 12 to $14 \mathrm{~h}$ apart. However, desert dust aerosols are indeed identified, and the summit altitude of the layers is compatible with the ground-based lidar observations. The CALIOP products from version 4.10 give BER values around $0.023 \mathrm{sr}^{-1}(\mathrm{LR}=44 \mathrm{sr})$ at $532 \mathrm{~nm}$. We have found BERs (LRs) between 0.025 and $0.031 \mathrm{sr}^{-1}$ (32 and $40 \mathrm{sr}$ ) at $355 \mathrm{~nm}$ from the ground-based lidar profiles, which compares well with CALIOP product, remaining within the error bars of the two lidars.

Incidentally, Haarig et al. (2017) have not found significant differences between LR values at 355 and $532 \mathrm{~nm}$ for desert dust aerosols transported over Barbados, but caution is due since neither the activated sources nor the transport durations are similar. Over the Balearic Islands, Chazette et al. (2016) report values of BER (LR) between 0.020 and $0.025 \mathrm{sr}^{-1}$ (40 and $50 \mathrm{sr}$ ) for the same type of acti- 

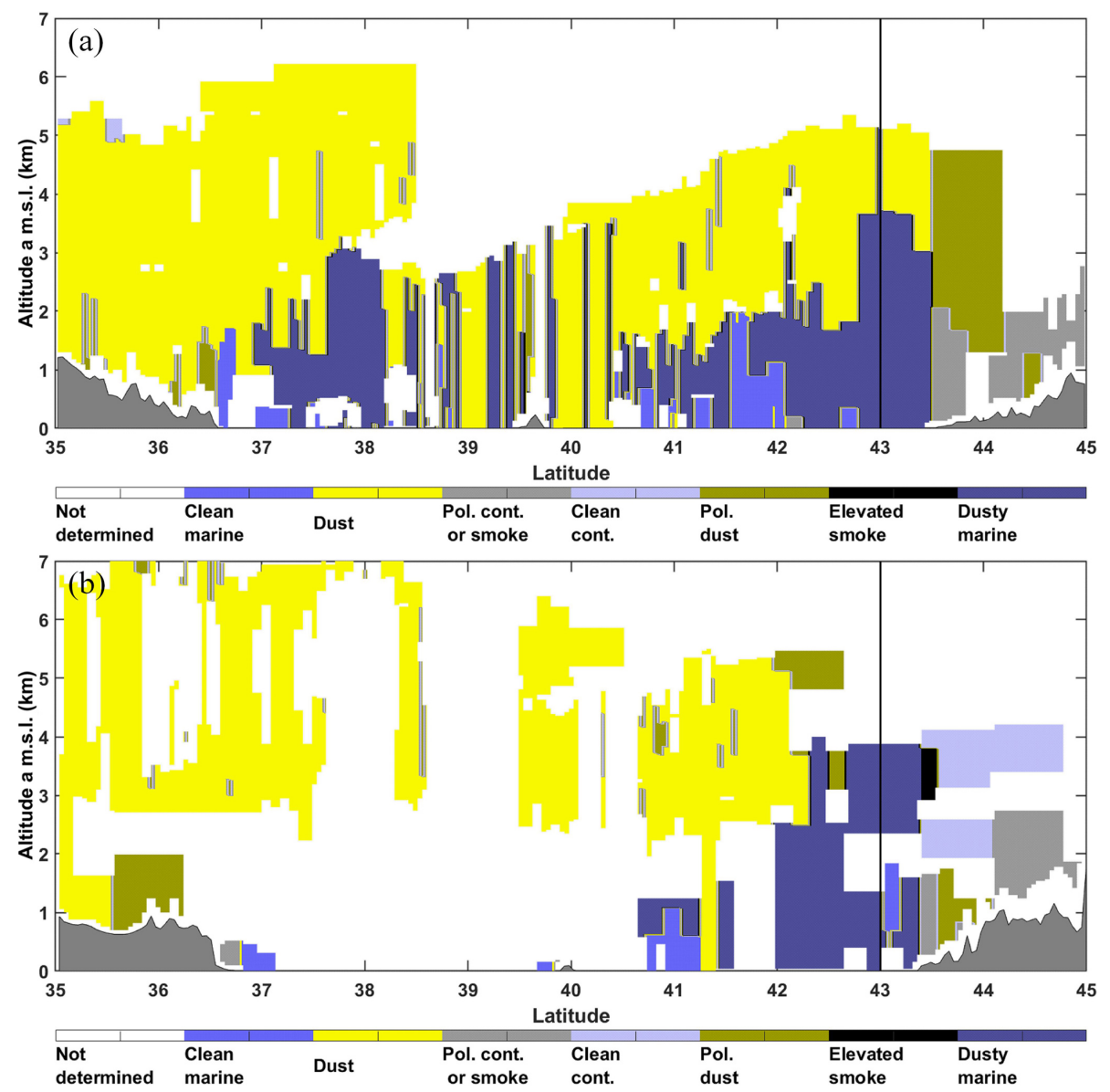

Figure 15. CALIOP-derived aerosol typing (version 4.10) for the nighttime orbit of (a) 24 June 2014 and (b) 3 July 2014 . The latitudinal location of the nearest latitude of the ground-based lidar is indicated by the vertical black line.

vated sources. In the synthesis table (Table 1) presented in Dieudonné et al. (2015), we note that BER (LR) values range from 0.017 to $0.029 \mathrm{sr}^{-1}$ ( 34 to $58 \mathrm{sr}$ ) for pure dust. Thus, there is a wide range of plausible values, which warrants a measurement of BERs (or LRs) as often as possible so as to properly invert lidar profiles.

\subsection{Other contributions}

The French Mediterranean coast is a densely populated area generating traffic and industrial emissions, identified by the "local" indicator in Figs. $2 \mathrm{~b}$ and $3 \mathrm{~b}$, but also with a frequent occurrence of forest fires (Guieu et al., 2005). Aerosol plumes are observed on 12-13 and 15-17 July in Fig. 3b above $1.5 \mathrm{~km}$ a.m.s.l. Back trajectories show northwestern contributions, which could be the result of wildfires. Indeed, their occurrence is high during this summer period in the hinterland, whose dry soils are covered mainly by garrigue and populations of cork and holm oaks, interspersed with some coniferous and palm trees. The equivalent BER of this plume is of the order of $0.022 \mathrm{sr}^{-1}$ and could correspond to a mixture of aerosols from biomass burning and terrigenous sources, as has been observed over the Mediterranean; see Fig. $2 b$ by Chazette et al. (2016). Nevertheless, as for the dust aerosols, the likely BER values for biomass burning aerosols are spread over a very wide range and depend on the type of fuel, the nature of the soil, and the intensity of the fires, all modulated by weather situations. The forest fires and bushfires are fortunately mastered quickly in this region, which makes it more difficult to detect them via MODIS.

\section{Conclusion}

For the first time, a backscatter $\mathrm{N}_{2}$-Raman lidar was implemented on the French Riviera and operated continuously during 3.5 weeks in June-July 2014. Coupled with a groundbased sun photometer, passive (MODIS and SEVIRI) and active (CALIPSO) spaceborne observations, and back trajectory modeling, this instrument made it possible to identify pollution aerosol transport in the low-medium free troposphere from the Mediterranean Spanish coast to the French Riviera. Two desert aerosol transport events have also been sampled by the lidar. The likely sources of aerosol plumes 
trapped in the free troposphere have thus been located. To our knowledge, the literature does not report the contribution to the AOT of pollution plumes from the eastern Spanish coast. These can represent nearly two-thirds of the total AOT and, given their anthropogenic origins, may have a significant effect on the vertical stability of the atmosphere in the coastal area. The air masses that contain them may also subside and recirculate along the coast, which is lined with mountains.

Desert aerosols sampled by the $\mathrm{N}_{2}$-Raman lidar come from the two major sources known in northwestern Africa: the Grand Erg Occidental and Grand Erg Oriental. There is no noticeable difference in optical properties retrieved from the lidar measurement between these two aerosol contributions. The backscatter-to-extinction ratios (lidar ratios) are similar, with values of $\sim 0.027 \mathrm{sr}^{-1}(\sim 37 \mathrm{sr})$ at $355 \mathrm{~nm}$. They are close to that derived from the CALIOP observations $\left(\mathrm{BER}=0.023 \mathrm{sr}^{-1}\right.$ or $\mathrm{LR}=44 \mathrm{sr}$ at $532 \mathrm{~nm}$ ). Pollution aerosols encountered in the free troposphere above the measurement site came from the Barcelona region (Costa Brava and Costa Daurada) as well as from the Murcia region (Costa Blanca). This second origin of pollution aerosol plumes was unexpected to this extent. These two sources can be mixed before reaching the western French Riviera, but they are also separately identifiable according to altitude. Transport altitudes are close to those of desert aerosol plumes, suggesting a similar injection process related to the large temperature difference between the sea surface and the continental air masses. Except for desert aerosols, an important point is the similarity of the BERs in the PBL and in the free troposphere. It is certainly related to the fact that locally produced aerosols, mainly due to traffic, have similar characteristics as those transported from Spain. The low sensitivity of the BER to relative humidity also probably contributes to this effect, and a likely air mass recirculation in the presence of mountain ranges close to the French Riviera coast may also tend to mix boundary layer and lower free tropospheric aerosols.

This study relies on a time-limited dataset ( $\sim 1$ month, $500 \mathrm{~h}$ of lidar measurements), but it raises questions as to the origin of the pollution aerosols that are sampled on the coast by the air quality stations, since the pollution may not be only local and also seems to be imported over the sea at the scale of the larger western Mediterranean basin. It would be interesting to implement lidar systems more densely and for a longer period in the French Riviera and further along Mediterranean coastlines, which are under very strong anthropic pressure. The interest in such an approach has been shown in previous works, in which it has been found that few lidar stations were required for an air quality forecasting similar to those constrained only by ground-based in situ measurements (Wang et al., 2013). A first test was also conducted within the framework of ChArMEx using the Earlinet network (Wang et al., 2014), which we may have to complete in the upcoming years to also meet the needs of operational meteorology to improve the forecasting of extreme events.
Data availability. Data can be downloaded from http://mistrals. sedoo.fr/ChArMEx/ (last access: 15 March 2019) upon request to the first author of the paper.

Author contributions. PC performed the experiment, analyzed the data, and wrote the paper; JT performed the experiment and participated in the paper editing; XS participated in the data analysis and the paper editing.

Competing interests. The authors declare that they have no conflict of interest.

Special issue statement. This article is part of the special issue "CHemistry and AeRosols Mediterranean EXperiments (ChArMEx) (ACP/AMT inter-journal SI)”. It is not associated with a conference.

Acknowledgements. The campaign was supported by the CNRS/INSU through the MISTRALS/ChArMEx and HyMeX programs. We especially thank François Dulac for his help in implementing the instrumental site and Jacques Piazzola for his welcome and the availability of the measurement site provided by the Mediterranean Institute of Oceanography. This work was supported by the Commissariat à l'Energie Atomique et aux énergies alternatives (CEA). The Centre National d'Etude Spatial (CNES) helped maintain the Raman-lidar instrument. The authors would like to thank the AERONET network for sun photometer products (https://aeronet.gsfc.nasa.gov/, last access: 15 March 2019). The authors acknowledge the MODIS Science, Processing and Data Support Teams for producing and providing MODIS data (https://modis.gsfc.nasa.gov/data/dataprod/, last access: 15 March 2019) and the Atmospheric Science Data Center (ASDC) at NASA Langley Research Center (LaRC) for the data processing and distribution of CALIPSO products (level 4.10; https://www-calipso.larc.nasa.gov/products/, last access: 15 March 2019). The authors would like to thank the entire MSG/SEVIRI team from ESA, Alcatel Space Industries, and Matra Marconi Space. SEVIRI data have been downloaded from the ICARE Data and Services Centre (http://www.icare.univ-lille1.fr/, last access: 15 March 2019). The NOAA Air Resources Laboratory (ARL) is acknowledged for the provision of the HYSPLIT transport and dispersion model and READY website (http://www.ready.noaa.gov, last access: 15 March 2019) used in this publication. ECMWF data used in this study have been obtained from the ESPRI/IPSL data server.

Review statement. This paper was edited by Oleg Dubovik and reviewed by two anonymous referees. 


\section{References}

Ancellet, G., Pelon, J., Totems, J., Chazette, P., Bazureau, A., Sicard, M., Di Iorio, T., Dulac, F., and Mallet, M.: Longrange transport and mixing of aerosol sources during the 2013 North American biomass burning episode: analysis of multiple lidar observations in the western Mediterranean basin, Atmos. Chem. Phys., 16, 4725-4742, https://doi.org/10.5194/acp16-4725-2016, 2016.

Balis, D., Papayannis, A., Galani, E., Marenco, F., Santacesaria, V., Hamonou, E., Chazette, P., Ziomas, I., and Zerefos, C.: Tropospheric LIDAR aerosol measurements and sun photometric observations at Thessaloniki, Greece, Atmos. Environ., 34, 925932, https://doi.org/10.1016/S1352-2310(99)00317-9, 2000.

Bennouna, Y. S., de Leeuw, G., Piazzola, J., and KusmierczykMichulec, J.: Aerosol remote sensing over the ocean using MSG-SEVIRI visible images, J. Geophys. Res., 114, D23203, https://doi.org/10.1029/2008JD011615, 2009.

Bouchlaghem, K., Ben Mansour, F., and Elouragini, S.: Impact of a sea breeze event on air pollution at the Eastern Tunisian Coast, Atmos. Res., 86, 162-172, https://doi.org/10.1016/J.ATMOSRES.2007.03.010, 2007.

Burton, S. P., Ferrare, R. A., Vaughan, M. A., Omar, A. H., Rogers, R. R., Hostetler, C. A., and Hair, J. W.: Aerosol classification from airborne HSRL and comparisons with the CALIPSO vertical feature mask, Atmos. Meas. Tech., 6, 13971412, https://doi.org/10.5194/amt-6-1397-2013, 2013.

Chazette, P., Pelon, J., Moulin, C., Dulac, F., Carrasco, I., Guelle, W., Bousquet, P., and Flamant, P.-H. P.-H.: Lidar and satellite retrieval of dust aerosols over the Azores during SOFIA/ASTEX, Atmos. Environ., 35, 4297-4304, https://doi.org/10.1016/S13522310(01)00253-9, 2001.

Chazette, P., Dabas, A., Sanak, J., Lardier, M., and Royer, P.: French airborne lidar measurements for Eyjafjallajökull ash plume survey, Atmos. Chem. Phys., 12, 7059-7072, https://doi.org/10.5194/acp-12-7059-2012, 2012.

Chazette, P., Totems, J., Ancellet, G., Pelon, J., and Sicard, M.: Temporal consistency of lidar observations during aerosol transport events in the framework of the ChArMEx/ADRIMED campaign at Minorca in June 2013, Atmos. Chem. Phys., 16, 28632875, https://doi.org/10.5194/acp-16-2863-2016, 2016.

Chazette, P., Totems, J., and Shang, X.: Atmospheric aerosol variability above the Paris Area during the 2015 heat wave - Comparison with the 2003 and 2006 heat waves, Atmos. Environ., 170, 216-233, https://doi.org/10.1016/j.atmosenv.2017.09.055, 2017.

Cholakian, A., Beekmann, M., Colette, A., Coll, I., Siour, G., Sciare, J., Marchand, N., Couvidat, F., Pey, J., Gros, V., Sauvage, S., Michoud, V., Sellegri, K., Colomb, A., Sartelet, K., Langley DeWitt, H., Elser, M., Prévot, A. S. H., Szidat, S., and Dulac, F.: Simulation of fine organic aerosols in the western Mediterranean area during the ChArMEx 2013 summer campaign, Atmos. Chem. Phys., 18, 7287-7312, https://doi.org/10.5194/acp18-7287-2018, 2018.

Chrit, M., Sartelet, K., Sciare, J., Pey, J., Nicolas, J. B., Marchand, N., Freney, E., Sellegri, K., Beekmann, M., and Dulac, F.: Aerosol sources in the western Mediterranean during summertime: a model-based approach, Atmos. Chem. Phys., 18, 96319659, https://doi.org/10.5194/acp-18-9631-2018, 2018.

Cros, B., Durand, P., Cachier, H., Drobinski, P., Fréjafon, E., Kottmeier, C., Perros, P. E., Peuch, V. H., Ponche, J. L.,
Robin, D., Saïd, F., Toupance, G., and Wortham, H.: The ESCOMPTE program: An overview, Atmos. Res., 69, 241-279, https://doi.org/10.1016/j.atmosres.2003.05.001, 2004.

Dalaudier, F., Sidi, C., Crochet, M., and Vernin, J.: Direct Evidence of "Sheets" in the Atmospheric Temperature Field, J. Atmos. Sci., 51, 237-248, https://doi.org/10.1175/15200469(1994)051<0237:DEOITA>2.0.CO;2, 1994.

Dall'Osto, M., Beddows, D. C. S., Pey, J., Rodriguez, S., Alastuey, A., Harrison, R. M., and Querol, X.: Urban aerosol size distributions over the Mediterranean city of Barcelona, NE Spain, Atmos. Chem. Phys., 12, 10693-10707, https://doi.org/10.5194/acp-12-10693-2012, 2012.

Di Biagio, C., Formenti, P., Doppler, L., Gaimoz, C., Grand, N., Ancellet, G., Attié, J.-L., Bucci, S., Dubuisson, P., Fierli, F., Mallet, M., and Ravetta, F.: Continental pollution in the Western Mediterranean basin: large variability of the aerosol single scattering albedo and influence on the direct shortwave radiative effect, Atmos. Chem. Phys., 16, 10591-10607, https://doi.org/10.5194/acp-16-10591-2016, 2016.

Dieudonné, E., Chazette, P., Marnas, F., Totems, J., and Shang, X.: Lidar profiling of aerosol optical properties from Paris to Lake Baikal (Siberia), Atmos. Chem. Phys., 15, 5007-5026, https://doi.org/10.5194/acp-15-5007-2015, 2015.

Dieudonné, E., Chazette, P., Marnas, F., Totems, J., and Shang, X.: Raman Lidar Observations of Aerosol Optical Properties in 11 Cities from France to Siberia, Remote Sens., 9, 978, https://doi.org/10.3390/rs9100978, 2017.

Dimitriou, K. and Kassomenos, P.: Quantifying daily contributions of source regions to PM concentrations in Marseille based on the trails of incoming air masses, Air Qual. Atmos. Heal., 11, 571580, https://doi.org/10.1007/s11869-018-0564-6, 2018.

El Haddad, I., D’Anna, B., Temime-Roussel, B., Nicolas, M., Boreave, A., Favez, O., Voisin, D., Sciare, J., George, C., Jaffrezo, J.-L., Wortham, H., and Marchand, N.: Towards a better understanding of the origins, chemical composition and aging of oxygenated organic aerosols: case study of a Mediterranean industrialized environment, Marseille, Atmos. Chem. Phys., 13, 78757894, https://doi.org/10.5194/acp-13-7875-2013, 2013.

Flamant, C., Trouillet, V., Chazette, P., and Pelon, J.: Wind speed dependence of atmospheric boundary layer optical properties and ocean surface reflectance as observed by airborne backscatter lidar, J. Geophys. Res.-Ocean., 103, 25137-25158, https://doi.org/10.1029/98JC02284, 1998.

Flamant, C., Chaboureau, J.-P., Chazette, P., Di Girolamo, P., Bourrianne, T., Totems, J., and Cacciani, M.: The radiative impact of desert dust on orographic rain in the Cévennes-Vivarais area: a case study from HyMeX, Atmos. Chem. Phys., 15, 1223112249, https://doi.org/10.5194/acp-15-12231-2015, 2015.

Granados-Muñoz, M. J., Navas-Guzmán, F., Guerrero-Rascado, J. L., Bravo-Aranda, J. A., Binietoglou, I., Pereira, S. N., Basart, S., Baldasano, J. M., Belegante, L., Chaikovsky, A., Comerón, A., D’Amico, G., Dubovik, O., Ilic, L., Kokkalis, P., Muñoz-Porcar, C., Nickovic, S., Nicolae, D., Olmo, F. J., Papayannis, A., Pappalardo, G., Rodríguez, A., Schepanski, K., Sicard, M., Vukovic, A., Wandinger, U., Dulac, F., and AladosArboledas, L.: Profiling of aerosol microphysical properties at several EARLINET/AERONET sites during the July 2012 ChArMEx/EMEP campaign, Atmos. Chem. Phys., 16, 70437066, https://doi.org/10.5194/acp-16-7043-2016, 2016. 
Guieu, C., Bonnet, S., Wagener, T., and Loÿe-Pilot, M. D.: Biomass burning as a source of dissolved iron to the open ocean?, Geophys. Res. Lett., 32, 1-5, https://doi.org/10.1029/2005GL022962, 2005.

Haarig, M., Ansmann, A., Althausen, D., Klepel, A., Groß, S., Freudenthaler, V., Toledano, C., Mamouri, R.-E., Farrell, D. A., Prescod, D. A., Marinou, E., Burton, S. P., Gasteiger, J., Engelmann, R., and Baars, H.: Triple-wavelength depolarizationratio profiling of Saharan dust over Barbados during SALTRACE in 2013 and 2014, Atmos. Chem. Phys., 17, 10767-10794, https://doi.org/10.5194/acp-17-10767-2017, 2017.

Hamonou, E., Chazette, P., Balis, D., Dulac, F., Schneider, X., Galani, E., Ancellet, G., and Papayannis, A.: Characterization of the vertical structure of Saharan dust export to the Mediterranean basin, J. Geophys. Res., 104, 22257, https://doi.org/10.1029/1999JD900257, 1999.

IPCC: Climate Change 2014: Impacts, Adaptation, and Vulnerability. Part A: Global and Sectoral Aspects. Contribution of Working Group II to the Fifth Assessment Report of the Intergovernmental Panel on Climate Change, edited by: Field, C. B., Barros, V. R., Dokken, D. J., Mach, K. J., Mastrandresa, M. D., Bilir, T. E., Chatterjee, M., Ebi, K. L., Estrada, Y. O., Genova, R. C., Girma, B., Kissel, E. S., Levy, A. N., MacCracken, S., Mastrandrea, P. R., and White, L. L., Cambridge University Press, Cambridge, NY, USA, UK, 2014.

Israelevich, P., Ganor, E., Alpert, P., Kishcha, P., and Stupp, A.: Predominant transport paths of Saharan dust over the Mediterranean Sea to Europe, J. Geophys. Res., 117, D02205, https://doi.org/10.1029/2011JD016482, 2012.

Knipping, E. M. and Dabdub, D.: Impact of chlorine emissions from sea-salt aerosol on coastal urban ozone, Environ. Sci. Technol., 37, 275-284, https://doi.org/10.1021/es025793z, 2003.

Lasry, F., Coll, I., and Buisson, E.: An insight into the formation of severe ozone episodes: modeling the 21/03/01 event in the ESCOMPTE region, Atmos. Res., 74, 191-215, https://doi.org/10.1016/J.ATMOSRES.2004.04.004, 2005.

Levy, I., Dayan, U., and Mahrer, Y.: A five-year study of coastal recirculation and its effect on air pollutants over the East Mediterranean region, J. Geophys. Res., 113, D16121, https://doi.org/10.1029/2007JD009529, 2008.

Levy, R. C., Mattoo, S., Munchak, L. A., Remer, L. A., Sayer, A. M., Patadia, F., and Hsu, N. C.: The Collection 6 MODIS aerosol products over land and ocean, Atmos. Meas. Tech., 6, 29893034, https://doi.org/10.5194/amt-6-2989-2013, 2013.

Mallet, M., Dulac, F., Formenti, P., Nabat, P., Sciare, J., Roberts, G., Pelon, J., Ancellet, G., Tanré, D., Parol, F., Denjean, C., Brogniez, G., di Sarra, A., Alados-Arboledas, L., Arndt, J., Auriol, F., Blarel, L., Bourrianne, T., Chazette, P., Chevaillier, S., Claeys, M., D’Anna, B., Derimian, Y., Desboeufs, K., Di Iorio, T., Doussin, J.-F., Durand, P., Féron, A., Freney, E., Gaimoz, C., Goloub, P., Gómez-Amo, J. L., Granados-Muñoz, M. J., Grand, N., Hamonou, E., Jankowiak, I., Jeannot, M., Léon, J.-F., Maillé, M., Mailler, S., Meloni, D., Menut, L., Momboisse, G., Nicolas, J., Podvin, T., Pont, V., Rea, G., Renard, J.-B., Roblou, L., Schepanski, K., Schwarzenboeck, A., Sellegri, K., Sicard, M., Solmon, F., Somot, S., Torres, B., Totems, J., Triquet, S., Verdier, N., Verwaerde, C., Waquet, F., Wenger, J., and Zapf, P.: Overview of the Chemistry-Aerosol Mediterranean Experiment/Aerosol Direct Radiative Forcing on the Mediterranean
Climate (ChArMEx/ADRIMED) summer 2013 campaign, Atmos. Chem. Phys., 16, 455-504, https://doi.org/10.5194/acp-16455-2016, 2016.

Millán, M. M., Artíñano, B., Alonso, L., Navazo, M., and Castro, M.: The effect of meso-scale flows on regional and long-range atmospheric transport in the western Mediterranean area, Atmos. Environ. A.-Gen. Top., 25, 949-963, https://doi.org/10.1016/0960-1686(91)90137-V, 1991.

Nabat, P., Somot, S., Mallet, M., Michou, M., Sevault, F., Driouech, F., Meloni, D., di Sarra, A., Di Biagio, C., Formenti, P., Sicard, M., Léon, J.-F., and Bouin, M.-N.: Dust aerosol radiative effects during summer 2012 simulated with a coupled regional aerosol-atmosphere-ocean model over the Mediterranean, Atmos. Chem. Phys., 15, 3303-3326, https://doi.org/10.5194/acp15-3303-2015, 2015.

Papayannis, A., Amiridis, V., Mona, L., Tsaknakis, G., Balis, D., Bösenberg, J., Chaikovski, A., De Tomasi, F., Grigorov, I., Mattis, I., Mitev, V., Müller, D., Nickovic, S., Pérez, C., Pietruczuk, A., Pisani, G., Ravetta, F., Rizi, V., Sicard, M., Trickl, T., Wiegner, M., Gerding, M., Mamouri, R. E., D'Amico, G., and Pappalardo, G.: Systematic lidar observations of Saharan dust over Europe in the frame of EARLINET (2000-2002), J. Geophys. Res., 113, D10204, https://doi.org/10.1029/2007JD009028, 2008.

Pappalardo, G., Amodeo, A., Pandolfi, M., Wandinger, U., Ansmann, A., Bösenberg, J., Matthias, V., Amiridis, V., De Tomasi, F., Frioud, M., Iarlori, M., Komguem, L., Papayannis, A., Rocadenbosch, F., and Wang, X.: Aerosol lidar intercomparison in the framework of the EARLINET project 3 Raman lidar algorithm for aerosol extinction, backscatter, and lidar ratio, Appl. Optics, 43, 5370, https://doi.org/10.1364/AO.43.005370, 2004.

Piazzola, J., Sellegri, K., Bourcier, L., Mallet, M., Tedeschi, G., and Missamou, T.: Physicochemical characteristics of aerosols measured in the spring time in the Mediterranean coastal zone, Atmos. Environ., 54, 545-556, https://doi.org/10.1016/j.atmosenv.2012.02.057, 2012.

Randriamiarisoa, H., Chazette, P., Couvert, P., Sanak, J., and Mégie, G.: Relative humidity impact on aerosol parameters in a Paris suburban area, Atmos. Chem. Phys., 6, 1389-1407, https://doi.org/10.5194/acp-6-1389-2006, 2006.

Raut, J.-C. and Chazette, P.: Vertical profiles of urban aerosol complex refractive index in the frame of ESQUIF airborne measurements, Atmos. Chem. Phys., 8, 901-919, https://doi.org/10.5194/acp-8-901-2008, 2008a.

Raut, J.-C. and Chazette, P.: Radiative budget in the presence of multi-layered aerosol structures in the framework of AMMA SOP-0, Atmos. Chem. Phys., 8, 6839-6864, https://doi.org/10.5194/acp-8-6839-2008, 2008b.

Royer, P., Chazette, P., Lardier, M., and Sauvage, L.: Aerosol content survey by mini $\mathrm{N}_{2}$-Raman lidar: Application to local and long-range transport aerosols, Atmos. Environ., 45, 7487-7495, https://doi.org/10.1016/j.atmosenv.2010.11.001, 2011.

Salmonson, V. V., Barnes, W. L. L., Maymon, P. W. P. W. P. W., Montgomery, H. E. H. E., and Ostrow, H.: MODIS: Advanced Facility Instrument for Studies of the Earth as a System, IEEE T. Geosci. Remote, 27, 145-153, https://doi.org/10.1109/36.20292, 1989.

Sicard, M., Barragan, R., Dulac, F., Alados-Arboledas, L., and Mallet, M.: Aerosol optical, microphysical and radiative 
properties at regional background insular sites in the western Mediterranean, Atmos. Chem. Phys., 16, 12177-12203, https://doi.org/10.5194/acp-16-12177-2016, 2016.

Sicard, P., Mangin, A., Hebel, P., and Malléa, P.: Detection and estimation trends linked to air quality and mortality on French Riviera over the 1990-2005 period, Sci. Total Environ., 408, 19431950, https://doi.org/10.1016/J.SCITOTENV.2010.01.024, 2010.

Stein, A. F., Draxler, R. R., Rolph, G. D., Stunder, B. J. B., Cohen, M. D., Ngan, F., Stein, A. F., Draxler, R. R., Rolph, G. D., Stunder, B. J. B., Cohen, M. D., and Ngan, F.: NOAA's HYSPLIT Atmospheric Transport and Dispersion Modeling System, B. Am. Meteorol. Soc., 96, 2059-2077, https://doi.org/10.1175/BAMSD-14-00110.1, 2015.

Wang, Y., Sartelet, K. N., Bocquet, M., and Chazette, P.: Assimilation of ground versus lidar observations for $\mathrm{PM}_{10}$ forecasting, Atmos. Chem. Phys., 13, 269-283, https://doi.org/10.5194/acp13-269-2013, 2013.
Wang, Y., Sartelet, K. N., Bocquet, M., Chazette, P., Sicard, M., D’Amico, G., Léon, J. F., Alados-Arboledas, L., Amodeo, A., Augustin, P., Bach, J., Belegante, L., Binietoglou, I., Bush, X., Comerón, A., Delbarre, H., García-Vízcaino, D., GuerreroRascado, J. L., Hervo, M., Iarlori, M., Kokkalis, P., Lange, D., Molero, F., Montoux, N., Muñoz, A., Muñoz, C., Nicolae, D., Papayannis, A., Pappalardo, G., Preissler, J., Rizi, V., Rocadenbosch, F., Sellegri, K., Wagner, F., and Dulac, F.: Assimilation of lidar signals: application to aerosol forecasting in the western Mediterranean basin, Atmos. Chem. Phys., 14, 12031-12053, https://doi.org/10.5194/acp-14-12031-2014, 2014.

Winker, D. M., Hunt, W. H., and McGill, M. J.: Initial performance assessment of CALIOP, Geophys. Res. Lett., 34, L19803, https://doi.org/10.1029/2007GL030135, 2007.

Yoon, Y. J., Ceburnis, D., Cavalli, F., Jourdan, O., Putaud, J. P., Facchini, M. C., Decesari, S., Fuzzi, S., Sellegri, K., Jennings, S. G., and O'Dowd, C. D.: Seasonal characteristics of the physicochemical properties of North Atlantic marine atmospheric aerosols, J. Geophys. Res.-Atmos., 112, D04206, https://doi.org/10.1029/2005JD007044, 2007. 